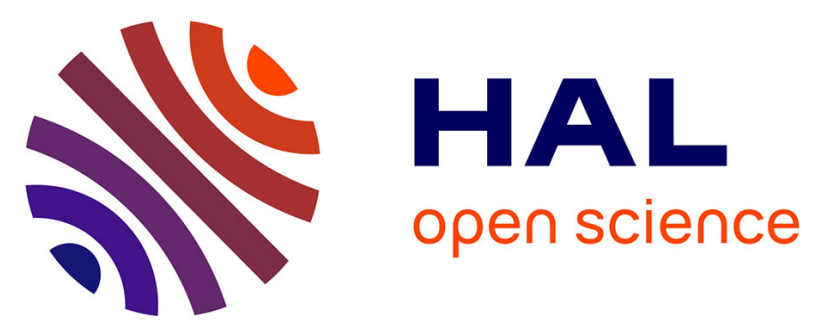

\title{
Synthesis, Self-Assembly, and Nucleic Acid Recognition of an Acylhydrazone-Conjugated Cationic Tetraphenylethene Ligand
}

Maëva Coste, Clément Kotras, Yannick Bessin, Virginie Gervais, David Dellemme, Maxime Leclercq, Mathieu Fossépré, Sébastien Richeter, Sébastien Clément, Mathieu Surin, et al.

\section{To cite this version:}

Maëva Coste, Clément Kotras, Yannick Bessin, Virginie Gervais, David Dellemme, et al.. Synthesis, Self-Assembly, and Nucleic Acid Recognition of an Acylhydrazone-Conjugated Cationic Tetraphenylethene Ligand. European Journal of Organic Chemistry, 2021, 2021 (7), pp.1123-1135. 10.1002/ejoc.202001420 . hal-03173850

\section{HAL Id: hal-03173850 \\ https://hal.umontpellier.fr/hal-03173850}

Submitted on 29 Sep 2021

HAL is a multi-disciplinary open access archive for the deposit and dissemination of scientific research documents, whether they are published or not. The documents may come from teaching and research institutions in France or abroad, or from public or private research centers.
L'archive ouverte pluridisciplinaire HAL, est destinée au dépôt et à la diffusion de documents scientifiques de niveau recherche, publiés ou non, émanant des établissements d'enseignement et de recherche français ou étrangers, des laboratoires publics ou privés. 


\title{
Synthesis, self-assembly and nucleic acid recognition of an acylhydrazone-conjugated cationic tetraphenylethene ligand
}

\author{
Maëva Coste, ${ }^{[a]}$ Clément Kotras, ${ }^{[b],[c]}$ Yannick Bessin, ${ }^{[a]}$ Virginie Gervais, ${ }^{[d]}$ David Dellemme, ${ }^{[c]}$ Maxime \\ Leclercq, ${ }^{[c]}$ Mathieu Fossépré, ${ }^{[c]}$ Sébastien Richeter, ${ }^{[b]}$ Sébastien Clément, ${ }^{*[b]}$ Mathieu Surin, ${ }^{*[c]}$ and \\ Sébastien Ulrich*[a]
}

[a] M. Coste, Dr. Y. Bessin, Dr. S. Ulrich

IBMM, Université de Montpellier, CNRS, ENSCM, Montpellier, France.

E-mail: sebastien.ulrich@enscm.fr

[b] Dr. C. Kotras, Dr. S. Richeter, Prof. S. Clément

ICGM Institut Charles Gerhardt Montpellier, UMR 5253, CNRS, Université de Montpellier, ENSCM, Montpellier, France.

E-mail : sebastien.clement1@umontpellier.fr

[c] Dr. C. Kotras, D. Dellemme, M. Leclercq, Dr. M. Fossépré, Dr. M. Surin

Laboratory for Chemistry of Novel Materials, Center of Innovation and Research in Materials and Polymers (CIRMAP), University of Mons-UMONS, 7000 Mons, Belgium

E-mail: mathieu.surin@umons.ac.be

[d] Dr. V. Gervais

CNRS, Institut de Pharmacologie et de Biologie Structurale (IPBS), Université de Toulouse, UPS, 205 route de Narbonne, 31077 Toulouse, France

Supporting information for this article is given via a link at the end of the document.

\begin{abstract}
Supramolecular polymers are of interest in the pursuit of multivalent nucleic acids recognition. However, their formation often relies on non-covalent forces that are also at play in the interaction with nucleic acids. In this work, we designed a novel compound (TPEGir) combining a tetraphenylethene aromatic core tethered to four quaternary ammoniums through acylhydrazone spacers, and we investigated in details its self-assembly and interaction with different types of nucleic acids. The spectroscopic analyses indicate the selfassembly of regular fluorescent nanoparticles (observed by DLS and TEM) in the absence of nucleic acids, the strong propensity to intercalate into single-stranded DNA, the ability to bind into the minor groove of double-stranded DNA, and the selective binding to Gquadruplex (G4) structures by fitting within a wide G4-groove. Those recognition events are quantified by isothermal titration calorimetry and the proposed binding models are supported by docking simulations.
\end{abstract}

\section{Introduction}

Supramolecular polymers are formed through the non-covalent association of monomers. An important class of supramolecular polymers features monomers, such as benzene-1,3,5triscarboxamides (BTAs), that associate through a combination of $\pi$-stacking interactions and hydrogen bonds into $1 \mathrm{D}$ rod-like supramolecular polymers in a cooperative fashion. ${ }^{[1]}$ However, the design may be particularly sensitive to the molecular structure and minute changes have been reported to greatly impact the nature of the resulting supramolecular polymers as well as their mechanisms of formation. ${ }^{[1-2]}$ These materials have attracted great interest in materials science for their dynamic self-healing properties, ${ }^{[3]}$ and have recently been considered for their potential application in life sciences. ${ }^{[4]}$ In particular, the dynamic expression of multivalency through controlled self-assembly and disassembly processes is an effective way toward smart biorecognition and delivery.

The recognition and delivery of nucleic acids requires multivalent binding which may be achieved using supramolecular polymers. ${ }^{[5]}$
However, interfacing supramolecular polymerization with DNA recognition is not straightforward since nucleic acids recognition involves multiple non-covalent forces (e.g. $\pi$-stacking, hydrogen bonds, electrostatic interactions) that may compete with the formation of supramolecular polymers. Thus, if the non-covalent interactions between aromatic monomers and the nucleic acids dominate, then those aromatic compounds can individually bind and self-organize onto nucleic acid templates, for instance through groove binding or intercalation through base pairs, ${ }^{[6]}$ as it is the case for cyanine and proflavine derivatives (Figure 1A). ${ }^{[6 b-e]}$ Alternatively, if the supramolecular polymer is robust to the presence of nucleic acid, a multivalent binding may happen, either through a programmed polymerization that take place prior to nucleic acid binding, ${ }^{[4 b, 7]}$ or in a nucleic acid-templated manner when supramolecular polymerization is triggered upon nucleic acid binding (Figure 1A) ${ }^{[8]}$ Examples of the latter case have been reported that involve the self-assembly, by $\pi-\pi$ stacking of $\pi$ conjugated compounds into supramolecular polymers (e.g. benzene ${ }^{[9]} /$ naphthalene ${ }^{[10]} /$ pyrene,${ }^{[11]}$ porphyrins, ${ }^{[12]}$ corroles,${ }^{[13]}$ perylene diimides, ${ }^{[14]}$ triarylamines, ${ }^{[15]}$ and oligo(p-phenylene vinylene $)^{[16]}{ }^{[5]}$ The divide between those modes of self-assembly rests on a delicate balance of forces (ligand-ligand interactions vs. ligand-DNA interactions) that still remain difficult to anticipate. Programmed self-assembly occurs when ligand-ligand interactions dominate whereas effective templated self-assembly requires both strong ligand-ligand and strong ligand-DNA interactions. ${ }^{[17]}$ In this case, having secondary interactions such as $\pi-\pi$ interactions between aromatic ligands can help strengthen ligand-ligand interactions.

In this context, compounds that feature a central aromatic $\pi$ conjugated core functionalized with cationic head groups through acylhydrazone linkages that can potentially give rise to intermolecular hydrogen bonds similarly to BTAs are of particular interest. We found effective DNA binding using Benz-Arg (Figure $1 \mathrm{~B})$, which was quite surprising and unexpected given the low valency of these compounds (6 positive charges from 3 guanidinium and 3 ammonium groups) and the lack of preorganization (the 3 cationic moieties being flexible and probably not oriented toward the same direction). ${ }^{[18]}$ Thus, we suspected 
that a self-assembly process may take place and account for the observed activity. In this work, we question the mode of selfassembly, whether these compounds lead to programmed or DNA-templated supramolecular polymers, or whether an alternative binding process takes place (see sketch Figure 1A). In a prior work, we set up on probing the role of hydrogen bonds which could be involved in BTAs-like supramolecular polymerization. However, gel electrophoresis and ethidium bromide displacement assay revealed no difference in DNA binding between Benz-Arg and its N-methylated version BenzArg $^{\text {Me }}$ (Figure 1B) which can act as a chain-stopper for supramolecular polymers, ${ }^{[19]}$ thereby ruling out the prime role of hydrogen bonds in this context. ${ }^{[20]}$ We then turned our attention to extended aromatic cores which could display exalted $\pi$-stacking interactions or hydrophobic interactions, and tetraphenylethene (TPE) as $\pi$-conjugated core was selected. TPE derivatives are well-known for their aggregation-induced emission (AIE) which results in an unusual enhancement of fluorescence emission upon aggregation. ${ }^{[21]}$ TPEs are therefore attractive candidates as turn-on fluorescent (bio)probes ${ }^{[22]}$ and supramolecular polymers incorporating TPE have thus been made. ${ }^{[23]}$ Besides, various TPE derivatives functionalized with cationic moieties, have been reported for the recognition of single-stranded (ss) DNA, ${ }^{[24]}$ double-stranded (ds) DNA, ${ }^{[24-25]}$ and DNA G-quadruplexes. ${ }^{[26]}$ While the nature of the pendant cationic groups (e.g. primary ammonium $v s$. quaternary ammonium) as well as the structure of the aromatic TPE core ( $E$ vs. $Z$ isomers) and thus the spatial presentation of those cationic groups have been found to play an important role on the binding affinity and selectivity, ${ }^{[24]}$ the role of self-assembly and the binding mode to DNA remain unclear. Herein, we report the design, synthesis, self-assembly and interaction with different types of DNA (ssDNA, dsDNA, and Gquadruplex) of compound TPE-Gir (Figure 1) that combines a TPE aromatic core, terminal quaternary ammonium groups for DNA binding through electrostatic interactions, and acylhydrazone spacers that can potentially form hydrogen bonds.

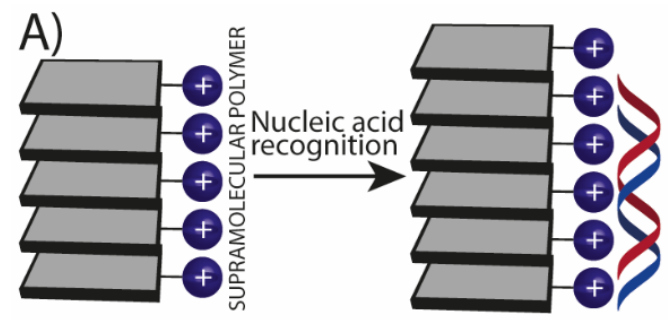<smiles>CNN(F)C(=O)C(N)CCCNC(N)=[NH2+]</smiles>

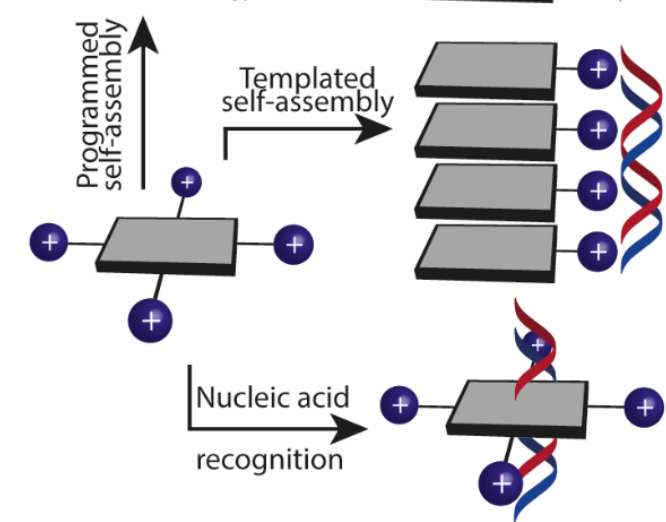<smiles></smiles>

$\operatorname{Benz-Arg}(\mathrm{R}=\mathrm{H})$ Benz-Arg $^{\mathrm{Me}}\left(\mathrm{R}=\mathrm{CH}_{3}\right)$<smiles>C[N+](C)(C)CC(=O)N/N=C/c1ccc(C(=C(c2ccc(/C=N/NC(=O)C[N+](C)(C)C)cc2)c2ccc(/C=N/NC(=O)C[N+](C)(C)C)cc2)c2ccc(/C=N/NC(=O)C[N+](C)(C)C)cc2)cc1</smiles>

Figure 1. A) Sketch of the possible modes of self-assembly of cationic aromatics: nucleic acid recognition of individual compounds through groove binding or base pair intercalation, templated self-assembly assisted by $\pi-\pi$ stacking, and programmed self-assembly of supramolecular polymers that recognize nucleic acids through multivalent interactions; B) Chemical structures of DNA-binding ligands made of different aromatic cores coupled to cationic moieties through acylhydrazone ligations. Counterions $\left(\mathrm{Cl}^{-}\right)$are omitted for clarity.

\section{Results and Discussion}

Design and synthesis. The design of TPE-Gir is based on a versatile click functionalization of a tetraphenylethene. We have recently described a TPE grafted with four aldehyde groups that can undergo subsequent acylhydrazone conjugation reaction. ${ }^{[27]}$ The acylhydrazone motif is indeed interesting for its well-known potential to engage in hydrogen bond interactions which often play a key role in supramolecular polymerization. ${ }^{28]}$

TPE-Gir was synthesized using acylhydrazone ligation reactions by reacting the tetraaldehyde TPE-AId ${ }^{[27]}$ with an excess (2 eq. per aldehyde) of the commercially-available Girard's reagent T (Scheme 1) in refluxing ethanol. The desired water-soluble TPE-
Gir was isolated by reverse-phase HPLC in $71 \%$ yield and characterized by NMR spectroscopy and mass spectrometry. The compound presents itself as an inseparable mixture of two isomers in a 7:3 ratio, assigned to $E / Z$ acylhydrazone isomers since the largest difference in chemical shift is seen for the imine proton (Figure S2) 


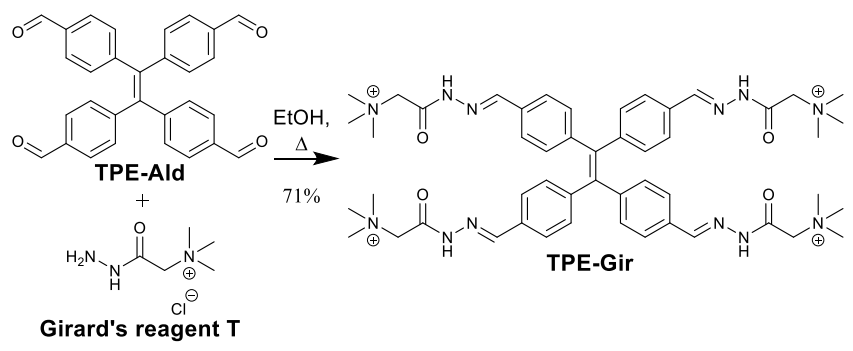

Scheme 1. Synthesis of TPE-Gir through acylhydrazone coupling reaction. Counterions $(\mathrm{Cl})$ are omitted in the structure of TPE-Gir, for clarity.

Self-assembly of TPE-Gir. We first studied the self-assembly properties of TPE-Gir. TPE-Gir appears molecularly-dissolved in aqueous buffer, probably due to repulsive electrostatic forces between the quaternary ammonium groups, whereas addition of a non-solvent such as THF leads to aggregation. This was evidenced by TEM analysis showing only few aggregates in $100 \%$ water, whereas numerous spherical objects with diameters centered around $100 \mathrm{~nm}$ are clearly seen in $\mathrm{THF} / \mathrm{H}_{2} \mathrm{O}$ 99/1 (v/v) (Figure 2A). DLS analysis provides a qualitative and quantitative confirmation, yielding Z-average diameters of $120 \mathrm{~nm}$ with a narrow polydispersity index of 0.14 (Figure $2 \mathrm{~B}$ ). In comparison, previous reports on different cationic TPE derivatives reported the formation of spherical objects with sizes ranging from 20 to 500 $\mathrm{nm} .{ }^{[29]}$ Further spectroscopic analyses reveal hypo- and bathochromic shifts in the electronic absorption spectra, respectively at $310 \mathrm{~nm}$ and $430 \mathrm{~nm}$, upon addition of THF - the effects being marked beyond $90 \%$ THF (Figure $2 \mathrm{C}$ ). The red-shift $(430 \mathrm{~nm}$ ) can be attributed to an extended conjugation, endowed by an enforced coplanarity of the acylhydrazone moieties with the central TPE core. Interestingly, fluorescence emission at $510 \mathrm{~nm}$ was found to be concomitantly increased 35-fold upon aggregation (Figure 2D). These results show that AIE operates on TPE-Gir thanks to the presence of a non-solvent triggering aggregation. However, unlike supramolecular polymers such as BTAs, in this case we did not evidence the formation of linear fibers but instead closed spherical structures, most likely vesicles due to the bola-amphiphilic character of TPE-Gir. ${ }^{[30]}$ The formation of such discrete objects may be the result of the frustrated growth of TPE-Gir which is favored by $\pi-\pi$ stacking interactions or hydrophobic effect and disfavored by electrostatic repulsion. ${ }^{[31]}$
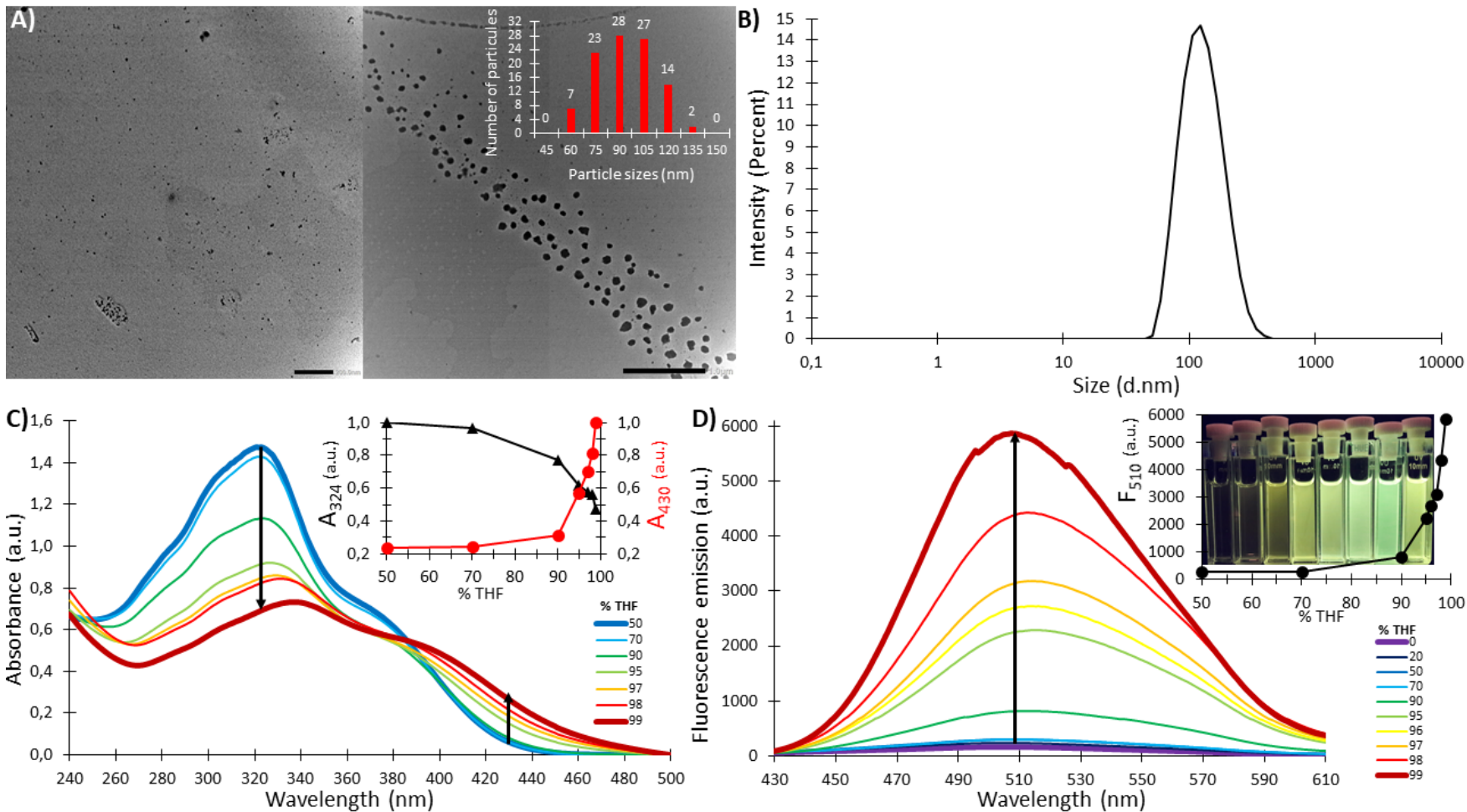

Figure 2. (A) TEM of TPE-Gir $(0.025 \mathrm{mM})$ : in $100 \% \mathrm{H}_{2} \mathrm{O}$ (left), in THF/ $\mathrm{H}_{2} \mathrm{O}$ 99/1 (right); (B) DLS analysis of TPE-Gir $(0.025 \mathrm{mM})$ in THF/ $\mathrm{H}_{2} \mathrm{O} 99 / 1$. HEPES buffer: $10 \mathrm{mM}$ HEPES, $9.4 \mathrm{mM} \mathrm{NaCl}, 10 \mu \mathrm{M}$ EDTA, pH 7.2; (C) UV-Visible absorption spectra of TPE-Gir (0.02 mM) in different THF/ HEPES (v/v) mixtures. Inset: Normalized evolution of TPE-Gir absorbances at 324 and $430 \mathrm{~nm}$; (D) Fluorescence emission spectra of TPE-Gir (0.02 mM) in different THF/ HEPES (v/v) mixtures $\left(\lambda_{\mathrm{exc}}=310 \mathrm{~nm}\right)$. Inset: Fluorescence emission evolution of TPE-Gir at $\lambda_{\mathrm{em}}=510 \mathrm{~nm}$; Photograph: samples at increasing $\mathrm{THF} / \mathrm{H}_{2} \mathrm{O}$ ratios (from left to right) $\mathrm{under}$ light irradiation $(310 \mathrm{~nm})$.

Interaction with single-stranded DNA. Single-stranded DNA serves as a popular template to organize small aromatic molecules into chiral nanostructures through electrostatic interactions with the phosphodiester backbone (outside binding) or hydrogen bonds with nucleobases. ${ }^{\left[{ }^{[3} \text { 32] }\right.}$ Although ssDNA is far less rigid than its double-stranded counterpart and best represented by a worm-like model, it keeps a helical structure with a persistence length that greatly increases under low salinity conditions (around $20 \AA$ below $10 \mathrm{mM} \mathrm{NaCl}$ ). ${ }^{[33]}$ Since TPE-Gir appears molecularly-dissolved in aqueous buffer, we envisaged 
that attractive electrostatic interactions by formation of ion pairs with phosphodiesters of ssDNA would favor their subsequent ssDNA-templated supramolecular polymerization. ${ }^{[9,15,34]}$ UV-Vis absorption spectroscopy of TPE-Gir shows continuous hypo- and batho-chromic shifts upon addition of single-stranded calf thymus DNA (ss-CT-DNA), while fluorescence emission shows a progressive increase of the main peak at $515 \mathrm{~nm}$ (Figures $3 \mathrm{~A}$ and $\mathrm{BB}$ ). Using an oligonucleotide template ( $\left.\mathrm{dT}_{40}\right)$, circular dichroism (CD) spectroscopy shows a bisignate signal with a zero-crossing at $247 \mathrm{~nm}$, and a weak negative induced CD (ICD) signal at $310 \mathrm{~nm}$ appearing as more TPE-Gir is titrated onto the solution of $\mathrm{dT}_{40}$ (Figure $3 \mathrm{C}$ ). The induced CD signal at $310 \mathrm{~nm}$ demonstrates that a close interaction takes place between $\mathrm{dT}_{40}$ and TPE-Gir, leading to a transfer of chirality from the chiral ssDNA template to the achiral ligand. Job plot analysis obtained through fluorescence titration experiments shows that a maximum is reached at a stoichiometry around 1 ligand per 3 nucleobases (Figure 3D).

Therefore, TPE-Gir binding to DNA manifests through hypochromism and a shift to longer wavelength in the absorption spectra of the bound ligand, ${ }^{[35]}$ along with a weak negative ICD signal, suggesting binding through intercalation. ${ }^{[36]} A$ partial "intercalation-like" complex ${ }^{[37]}$ could be evoked where the TPE core would stack between nucleobases while the quaternary ammonium group would interact through electrostatic interaction with the DNA phosphodiester backbone. ${ }^{[38]}$ Thus, the enhancement in fluorescence emission is better explained by the restriction of intramolecular rotation due to intercalation within nucleobases rather than an effect promoted by aggregation. ${ }^{339]}$
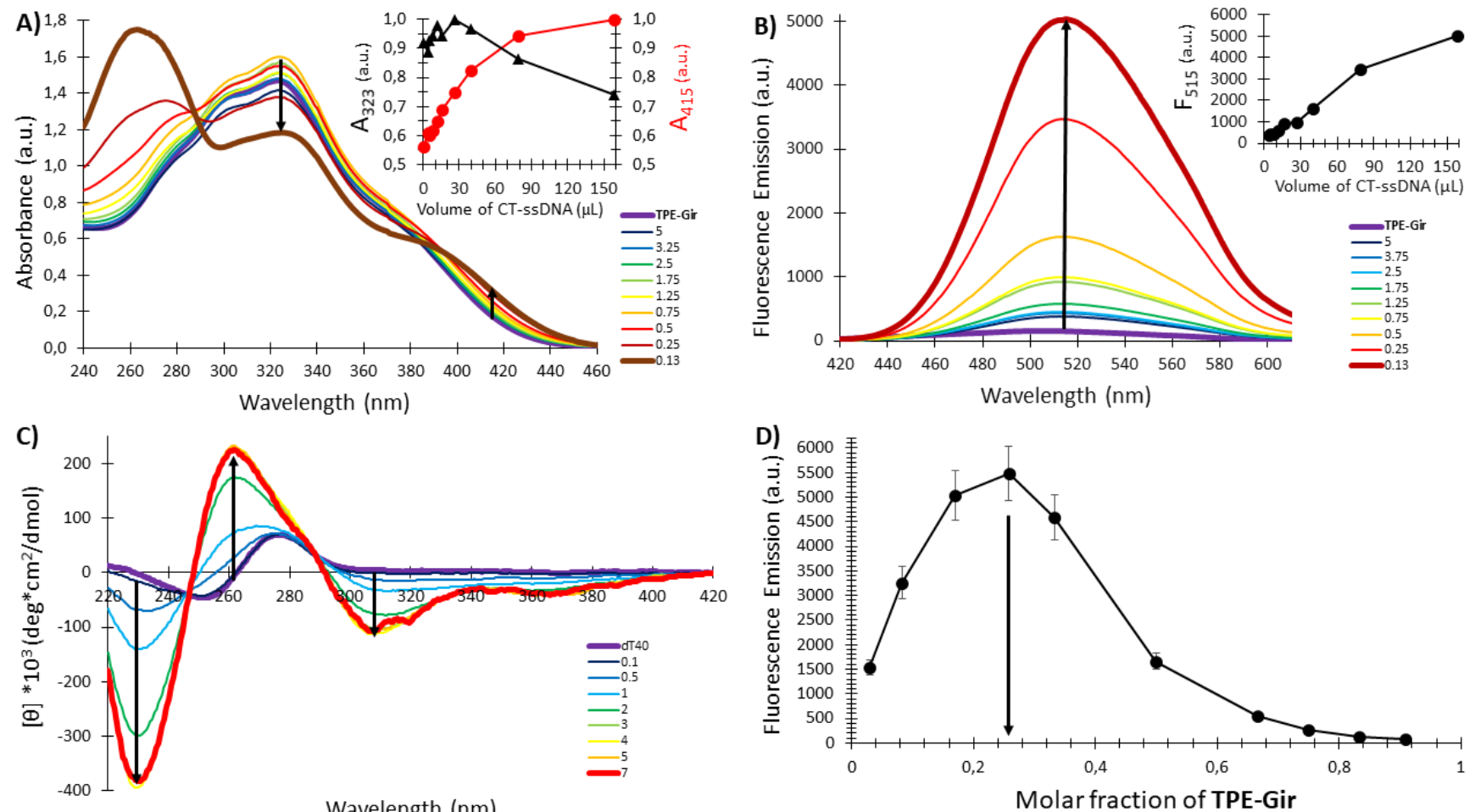

Figure 3. (A) UV-Visible titration of TPE-Gir (0.02 mM in HEPES) by ssCT-DNA at different molar ratios (final concentrations of $0.2 \mathrm{nM}$ to $8 \mathrm{nM}$ ). Inset: Normalized evolution of TPE-Gir:ssCT-DNA absorbances at different volumes of ssCT-DNA ( $\lambda_{\mathrm{abs}}=323$ and $415 \mathrm{~nm}$ ); (B) Fluorescence emission spectra of TPE-Gir (0.02 mM in HEPES) by sSCT-DNA at different molar ratios (final concentrations of $0.2 \mathrm{nM}$ to $8 \mathrm{nM})\left(\lambda_{\mathrm{exc}}=310 \mathrm{~nm}\right.$ ). Inset: Fluorescent emission evolution of TPE-Gir:ssCTDNA spectra at different volumes of SsCT-DNA $\left(\lambda_{\mathrm{em}}=515 \mathrm{~nm}\right) ;(C) \mathrm{CD}$ titration of $\mathrm{dT}_{40}$ (final concentration of $13 \mu \mathrm{M}$ in water) by TPE-Gir at different molar ratios in $\mathrm{H}_{2} \mathrm{O}$ (final concentration of TPE-Gir of $0.012 \mathrm{mM}$ to $0.6 \mathrm{mM}$ ); (D) Job plot obtained through fluorescence titration experiments (relative error of $10 \%$ applied) The molar ratios are expressed in ligand per nucleobase. HEPES buffer: $10 \mathrm{mM} \mathrm{HEPES,} 9.4 \mathrm{mM} \mathrm{NaCl}, 10 \mu \mathrm{M}$ EDTA, pH 7.2.

Given the larger surface of TPE-Gir compared to nucleobases, we wondered whether such partial "intercalation-like" complex could leave room to the assembly of multiple ssDNA. Indeed, the observed binding stoichiometry of 1 ligand per 3 nucleobases has not reached the maximal value dictated by the nearest neighbor site exclusion principle ${ }^{[40]}$ of 1 ligand per 2 nucleobases (Figure 4A). Alternatively, such binding stoichiometry could potentially fit a binding model involving two ssDNA strands, thus giving a stoichiometry of 1 ligand per 4 nucleobases (i.e. 2 pseudo base pairs) (Figure 4B). In order to probe the existence of such binding, we used (5'-FAM)- $\mathrm{dT}_{40}$ and $\mathrm{dT}_{40}$-(3'-TAMRA) as fluorescentlabelled ssDNA probes with FAM (Ex. $495 \mathrm{~nm}, \mathrm{Em} .516 \mathrm{~nm}$ ) and
TAMRA (Ex. 520 nm, Em. 581 nm) acting as Fluorescence Resonance Energy Transfer (FRET) donor and acceptor dyes, respectively. The results revealed that upon addition of those two ssDNA probes onto a solution of TPE-Gir in saline water $(150 \mathrm{mM}$ $\mathrm{NaCl}$ ), an increasing FRET signal, monitored by the $\mathrm{F}_{581} / \mathrm{F}_{516}$ fluorescence emission ratio, occurred up to the stoichiometry of 1 ligand per 2 nucleobases where its maximal value - 13-fold greater than without TPE-Gir - was reached (Figure 4C). Using (5'-FAM)- $\mathrm{dT}_{40}$ and (5'-TAMRA)- $\mathrm{dT}_{40}$, a similar result was obtained with the maximum of the $F_{581} / F_{516}$ fluorescence emission ratio reached at the stoichiometry of 1 ligand per 4 nucleobases. However, the magnitude of the FRET signal was limited to a 4 - 
fold increase compared to the experiment conducted in the absence of TPE-Gir (Figure 4D). These results confirm the formation of the ligand-templated pseudo-duplexes (Figure 4B) and show that an antiparallel arrangement of the two ssDNA strands remains preferred compared to a parallel arrangement. Given the previously-determined binding stoichiometry of 1 ligand per 3 nucleobases, most likely the two proposed binding models - partial "intercalation-like" of TPE-Gir in a single ssDNA strand and ligand-templated pseudo-duplex formation - depicted in Figure $4 \mathrm{~A}$ and $4 \mathrm{~B}$ respectively, co-exist in a dynamic equilibrium in the conditions used in this study. The $F_{581} / F_{516}$ fluorescence emission ratio strongly and gradually decreases with heating (Figure S3, ESI), confirming a statistical non-cooperative pseudo duplex formation. The process is fully reversible over a complete cooling/heating cycle.
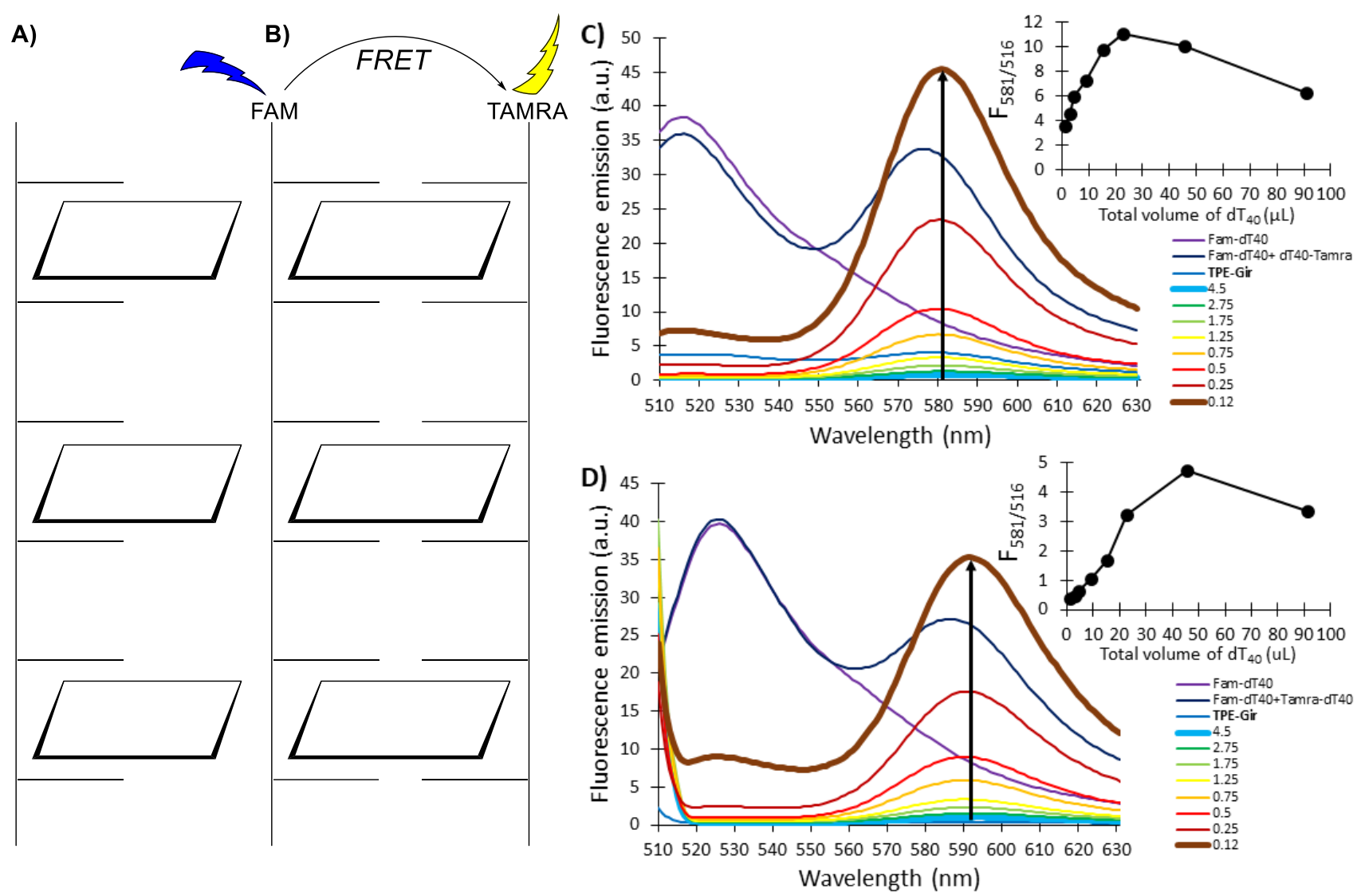

Figure 4. Schematic representation of the different binding modes of a m-conjugated ligand in A) single ssDNA following a nearest neighbor site exclusion principle, B) two ssDNA strands arranged in parallel/antiparallel pseudo-duplexes which formation can be evidenced using a FRET assay as depicted here (see text for details); and FRET titration experiments of TPE-Gir (0.02 mM) at different molar ratios (4.5-0.12) by C) FAM-dT 40 and dT $40-\left(3^{\prime}-\right.$ TAMRA , or D) FAM-dT 40 and (5'TAMRA)-dT 40 ; insets plotting the $\mathrm{F}_{581} / \mathrm{F}_{516}$ fluorescence ratio at different ligand per nucleobase molar ratios. Ex. $495 \mathrm{~nm}$, Em. $581 \mathrm{~nm}$.

Interaction with double-stranded DNA. Interaction with dsDNA can take place through intercalation, groove-binding, or outside binding - the latter occurring by salt bridge interactions with the phosphodiester backbone and is usually promoted in conditions of low salinity. Spectroscopic analyses were carried out using calfthymus DNA. The spectroscopic data match those previously obtained with ssDNA in that UV-Vis absorption spectroscopy show hypo- and batho-chromic shifts when adding dsDNA, the fluorescence emission gradually increases at $515 \mathrm{~nm}$, and CD spectroscopy shows a negative ICD signal at $310 \mathrm{~nm}$ (Figure 5). Not surprising given the more defined helical arrangement of dsDNA, the molar ellipticity in this case is much higher than with ssDNA (compare Figures 5C with $3 \mathrm{C}$ ). The Job plot analysis reveals a binding stoichiometry around 1 ligand per 3 base pairs, in fairly good agreement with the nearest neighbor site exclusion principle, which could suggest a binding through intercalation (Figure 5D). ${ }^{[40]}$ However, it is important to be cautious regarding the interpretation of ICD signals, given the different mechanisms that contribute to these signals, as detailed for a dsDNA minor groove binder such as DAPI (4',6-diamidino-2-phenylindole). ${ }^{[41]}$ Interestingly, we can also notice, from the CD spectra, changes in DNA structure (positive band shifted from 280 to $260 \mathrm{~nm}$; negative band shifted from 245 to $230 \mathrm{~nm}$ ) that could indicate a B-to-A helix conversion in the presence of TPE-Gir (Figure 5C). ${ }^{[42]}$ The marked AIE effect was further evidenced in gel electrophoresis experiments where luminescent bands for complexed plasmids are observed when irradiated at $320 \mathrm{~nm}$ (Figure S3, ESI) - an essential but not sufficient prerequisite for "light-up" probes. ${ }^{\text {[25b, 26a] }}$ 

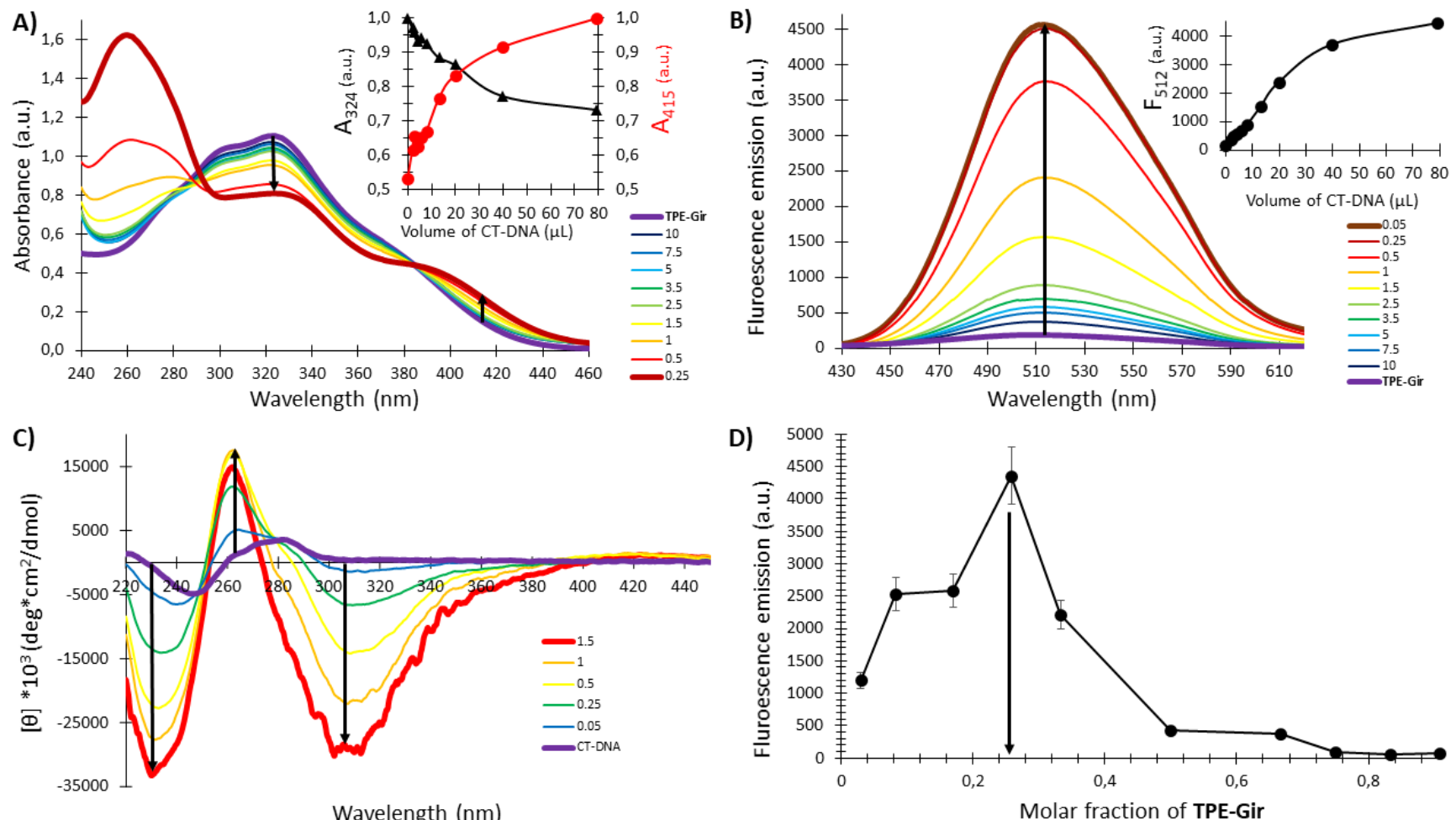

Figure 5. A) UV-Visible titration of TPE-Gir (0.02 mM in HEPES) by CT-DNA at different molar ratios (final concentrations of $0.1 \mathrm{nM}$ to $4 \mathrm{nM}$ ). Inset: Normalized evolution of TPE-Gir: CT-DNA absorbances at different volumes of CT-DNA ( $\lambda_{\mathrm{exc}}=324$ and $\left.415 \mathrm{~nm}\right)$; (B) Fluorescence emission spectra of TPE-Gir (0.02 mM in HEPES) by CT-DNA at different molar ratios (final concentrations of $0.1 \mathrm{nM}$ to $4 \mathrm{nM})\left(\lambda_{\mathrm{exc}}=310 \mathrm{~nm}\right)$. Inset: Fluorescent emission evolution of TPE-Gir:CT-DNA spectra at different volumes of CT-DNA $\left(\lambda_{\mathrm{em}}=515 \mathrm{~nm}\right.$ ); (C) CD titration spectra of CT-DNA (final concentration of $2.11 \mathrm{nM}$ in water) by TPE-Gir at different molar ratios in $\mathrm{H}_{2} \mathrm{O}$ (final concentration of TPE-Gir of $2 \mu \mathrm{M}$ to $60 \mu \mathrm{M}$ ); (D) Job plot obtained through fluorescence titration experiments (relative error of $10 \%$ applied). The molar ratios are expressed in ligand per base pair. HEPES buffer: $10 \mathrm{mM} \mathrm{HEPES,} 9.4 \mathrm{mM} \mathrm{NaCl}, 10 \mu \mathrm{M}$ EDTA, pH 7.2.

Interaction with DNA G-quadruplexes. G-quadruplexes (G4s) are folded secondary structures of nucleic acids, formed in guanine-rich sequences that are assembled into stacks of planar G-quartets in the presence of templating monovalent cations. DNA G4s are present in telomeres and their abnormal persistence has been linked to cancer cells avoiding entering senescence/apoptosis. Therefore, ligands that would interact and stabilize G-quadruplexes in tumor cells so that telomere repair by telomerases is inhibited, ultimately restoring senescence/apoptosis, bear a strong pharmaceutical interest. ${ }^{[43]}$ Examples of ligand families are acridines, bisquinoliniums, porphyrin, naphthalene- and perylene-diimides which interact with G4 targets by electrostatic interactions with the loops and by $\pi$ type interactions with G-quartets. ${ }^{[44]}$ In this line, we have recently evidenced the selective binding of different ligands for Gquadruplexes, ${ }^{[45]}$ including some based on TPE that have also been explored by us ${ }^{[26 a]}$ and others, ${ }^{[26 d]}$ finding important effects related to the nature of the spacers connecting the central aromatic core with the peripheral cationic groups. ${ }^{[26 b, 26 c]}$ Due to the strong propensity of TPE-Gir to engage in $\pi$ stacking interactions with nucleobases and its original acylhydrazone spacer, we were interested in its binding properties to Gquadruplexes. We have selected a human telomeric DNA sequence Tel22 (5'-AGG GTT AGG GTT AGG GTT AGG G-3') for its biological relevance. This sequence has been shown to adopt an anti-parallel conformation in presence of $100 \mathrm{mM} \mathrm{Na}^{+}$, while it adopts mixed parallel and antiparallel conformations in presence of $\mathrm{K}^{+}{ }^{[46]}$ Indeed, CD spectra of Tel22 in Tris-EDTA (TE) buffer in absence and in presence of $\mathrm{K}^{+}$show positive and negative peaks, at $293 \mathrm{~nm}$ and $235 \mathrm{~nm}$ respectively, indicative of hybrid G-quadruplexes conformations, which may differ in loop arrangement, strand orientations and tetrad arrangements. In the presence of $\mathrm{Na}^{+}$, the anti-parallel conformation is preferred as indicated by specific CD signals (positive at $295 \mathrm{~nm}$ and negative at $262 \mathrm{~nm}$ ) (Figure 6A). ${ }^{[4]}$ In presence of TPE-Gir, for a Tel22:TPE-Gir (1:1) mixture, the CD signature of the anti-parallel conformation is globally maintained, although different intensities are noted. In contrast, Tel22 binding by TPE-Gir in a 1:5 ratio produces a hybrid topology. The hybrid is characterized by a positive CD signal at $292 \mathrm{~nm}$ with a distinct shoulder at $\sim 270 \mathrm{~nm}$ as well as a strong negative peak at $235 \mathrm{~nm}$. The G4-ligand interaction is also evidenced by the broad negative ICD signal observed in the 310-350 nm range where TPE-Gir absorbs, due to the induction of chirality from G4 to TPE-Gir (Figure 6B). Fluorescence emission spectra show a strong enhancement $(\sim 15$ fold) and a small $(10 \mathrm{~nm})$ red-shift of the emission band of TPEGir in the presence of G-quadruplex (Figure 6C). Finally, we assessed the stabilization of G-quadruplex and the binding selectivity of TPE-Gir by thermal denaturation through a FRET assay. ${ }^{[48]}$ For this purpose, we used a modified Tel22, named F21T, appended with a FAM dye at position 5' and a TAMRA dye at position $3^{\prime}{ }^{\text {[26a] }}$ The results show a significant increase in the melting temperature $\left(\Delta T_{1 / 2}=16^{\circ} \mathrm{C}\right)$ that indicates a strong stabilization of this G4 structure (Figure $6 \mathrm{D}$ ). This value is close 
to that reported for tetraimidazolium tetraphenylethene (TPE-Im) $\left(\Delta \mathrm{T}_{1 / 2}=19.5^{\circ} \mathrm{C}\right)^{[26 \mathrm{a}]}$ and slightly lower than ligands with larger aromatic cores such as tetrakis $(\mathrm{N}$-methylpyridinium-4yl)porphyrin $\left(\Delta \mathrm{T}_{1 / 2}=23^{\circ} \mathrm{C}\right)$ or tetraimidazolium-fused porphyrin $\left(\Delta \mathrm{T}_{1 / 2}=25^{\circ} \mathrm{C}\right) .{ }^{[45 \mathrm{c}]}$ Nevertheless, no decrease of this melting temperature is noted after addition of 10 equivalents of a random sequence dsDNA (with 43 base pairs), which points toward a great selectivity of TPE-Gir for G4 compared to dsDNA, possibly due to more important $\pi-\pi$ interactions (see below).
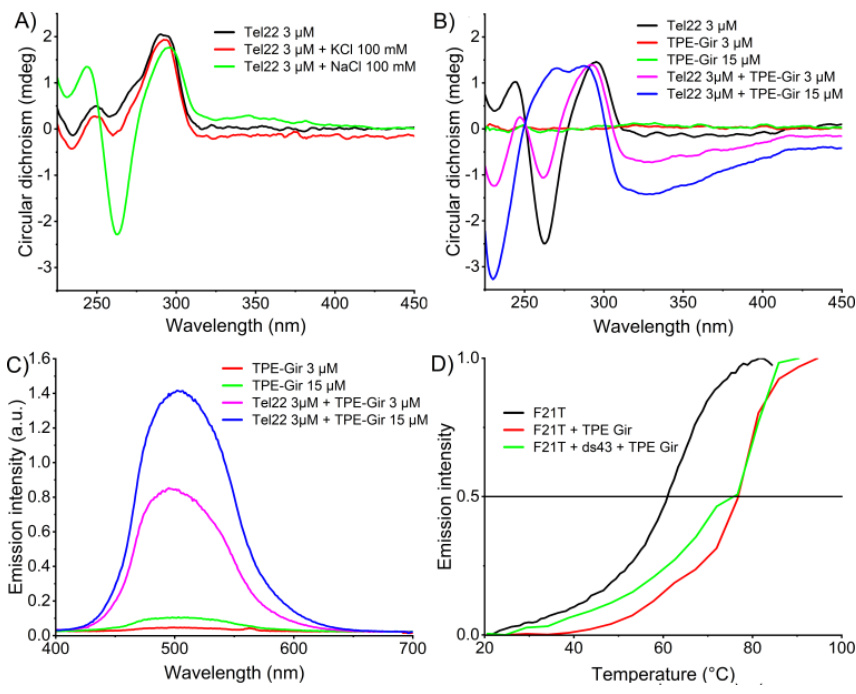

Figure 6. A) CD Spectra of pure Tel22 $(3 \mu \mathrm{M})$ in TE buffer $(\mathrm{pH} 7.4)$, in presence of $100 \mathrm{mM} \mathrm{K}^{+}$and $100 \mathrm{mM} \mathrm{Na}^{+}$; B) CD Spectra of pure Tel22 $(3 \mu \mathrm{M})$, pure TPEGir $(3 \mu \mathrm{M}$ and $15 \mu \mathrm{M})$ and Tel22:TPE-Gir mixture at 1:1 and 1:5 molar ratio in TE buffer $(\mathrm{pH} 7.4)$ in presence of $100 \mathrm{mM} \mathrm{Na}^{+}$; C) Fluorescence emission spectra $\left(\lambda_{\text {exc }}=269 \mathrm{~nm}\right)$ of pure TPE-Gir $(3$ and $15 \mu \mathrm{M})$ and Tel22:TPE-Gir mixture at 1:1 and 1:5 molar ratio in TE buffer in presence of $100 \mathrm{mM} \mathrm{Na}^{+}$; D) Thermal denaturation by FRET assay using F21T alone, F21T:TPE-Gir mixture (1:5 molar ratio) and F21T:TPE-Gir:ds43-dsDNA mixture (1:5:10 molar ratio) with dsDNA ds 43 as competitor in lithium-cacodylate buffer $(10 \mathrm{mM}, 100$ $\mathrm{mM} \mathrm{K}^{+}, \mathrm{pH}$ 7.2). The FAM emission at $516 \mathrm{~nm}\left(\lambda_{\mathrm{exc}}=492 \mathrm{~nm}\right)$ has been normalized.

Determination of binding constants. Isothermal titration calorimetry (ITC) experiments were carried out in order to estimate the equilibrium association constants $\left(K_{a}\right)$ between TPEGir and nucleic acids, in particular with two very different types of nucleic acids (ssDNA dT 40 and G-quadruplex Tel22). Table 1 provides the thermodynamic parameters in two buffered solutions containing either $150 \mathrm{mM} \mathrm{NaCl}$ or $\mathrm{KCl}$.

The interactions with $\mathrm{dT}_{40}$ is salt-independent and appears enthalpy-driven with a moderate association constant $\mathrm{K}_{\mathrm{a}}=6.5$ $10^{4} \mathrm{M}^{-1}$ (Table 1). This value, along with the binding stoichiometry of around 11-14 ligands per $\mathrm{dT}_{40}$ (i.e. 1 ligand per 2.8-3.6 nucleobase) fits very well the data previously obtained by the Job plot method ( 1 ligand per 3 nucleobases, vide supra). From these data, one can calculate ${ }^{[6 \mathrm{~b}]}$ that $96 \%$ of TPE-Gir ligands are bound under these conditions.

The thermodynamic parameters for TPE-Gir with Tel22 are markedly different. First, an obvious salt effect was observed (Table 1). While a single exothermic binding profile was observed for the interaction of TPE-Gir with Tel22 in its $\mathrm{Na}^{+}$form - with an affinity of $2.6 \times 10^{5} \mathrm{M}^{-1}$ and a stoechiometry of 0.5 , the shape of the ITC isotherm for TPE-Gir binding to Tel22 in its $\mathrm{K}^{+}$form indicated a biphasic binding event. In this two-site binding profile, an initial binding event $\left(\mathrm{K}_{\mathrm{a}}=1.4 \times 10^{5} \mathrm{M}^{-1}\right)$ requiring a low TPEGir/Tel22 ratio to reach saturation was first observed, followed by a stronger secondary process $\left(\mathrm{K}_{\mathrm{a}}=1.53 \times 10^{6} \mathrm{M}^{-1}\right)$. A possible explanation for such two-step binding could be that the initial binding of TPE-Gir induces a conformational rearrangement of Tel22, forcing the G-quadruplex to adopt a unique fold ( $1^{\text {st }}$ binding event - stoichiometry in the same range than in $\mathrm{Na}^{+}$conditions), while additional ligands are subsequently externally bound $\left(2^{\text {nd }}\right.$ binding event, $\mathrm{N}=4$ ) as previously shown. ${ }^{[49]}$ Overall, these data confirm that TPE-Gir polyintercalate weakly in sSDNA and displays selective binding to $G$ quadruplexes with sensitivity to the

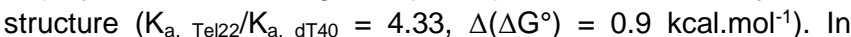
contradiction to our previous results, ${ }^{[50]}$ binding to CT-DNA could unfortunately not be properly quantified by ITC in those conditions. Instead, the corresponding binding constant was determined from the UV-Vis titration (Figure 5A), monitored at 325 and $430 \mathrm{~nm}$, using the Benesi-Hildebrand equation. ${ }^{[51]}$ An apparent binding constant $\mathrm{K}_{\mathrm{a}}=3.7-10.8 \times 10^{4} \mathrm{M}^{-1}$ was determined, which confirms a weaker binding of TPE-Gir to CT-DNA as compared to G quadruplex Tel22.

Table 1. Thermodynamic parameters derived from Isothermal Titration calorimetry binding studies for the binding of TPE-Gir to $\operatorname{ssDNA~dT}_{40}$ and Gquadruplex Tel22. Experiments were conducted in a TE buffer $(50 \mathrm{mM}, \mathrm{pH} 6.5)$, in presence of $150 \mathrm{mM} \mathrm{NaCl}\left(\mathrm{Na}^{+}\right.$form) or $150 \mathrm{mM} \mathrm{KCl}\left(\mathrm{K}^{+}\right.$form).

\begin{tabular}{|c|c|c|c|c|c|}
\hline & $\begin{array}{c}\mathrm{dT}_{40}, \\
\mathrm{Na}^{+} \\
\text {buffer }\end{array}$ & $\begin{array}{c}\mathrm{dT}_{40}, \\
\mathrm{~K}^{+} \\
\text {buffer }\end{array}$ & $\begin{array}{c}\text { Tel22, } \\
\mathrm{Na}^{+} \\
\text {form }\end{array}$ & \multicolumn{2}{|c|}{$\begin{array}{c}\text { Tel22, } \\
\mathrm{K}^{+} \\
\text {form }\end{array}$} \\
\hline $\begin{array}{c}K_{d} \\
(\mu M)\end{array}$ & 17 & 14 & 3.8 & 0.7 & 7 \\
\hline $\begin{array}{c}\mathrm{K}_{\mathrm{a}} \\
\left(10^{6} \mathrm{M}^{-1}\right)\end{array}$ & $\begin{array}{c}0.06 \\
\pm 0.01\end{array}$ & $\begin{array}{c}0.07 \\
\pm 0.01\end{array}$ & $\begin{array}{l}0.26 \\
\pm 0.1\end{array}$ & $\begin{array}{r}1.53 \\
\pm 0.3\end{array}$ & $\begin{array}{c}0.14 \\
\pm 0.02\end{array}$ \\
\hline $\begin{array}{c}\Delta \mathrm{H} \\
\left(\mathrm{kcal}^{\mathrm{mol}}{ }^{-1}\right)\end{array}$ & $\begin{array}{l}-6.24 \\
\pm 0.1\end{array}$ & $\begin{array}{l}-6.9 \\
\pm 0.1\end{array}$ & $\begin{array}{l}-2.9 \\
\pm 0.3\end{array}$ & $\begin{array}{r}0.10 \\
\pm 0.1\end{array}$ & $\begin{array}{l}2.47 \\
\pm 0.1\end{array}$ \\
\hline $\begin{array}{c}-\mathrm{T} \Delta \mathrm{S} \\
\left(\mathrm{kcal}^{\mathrm{mol}}{ }^{-1}\right)\end{array}$ & -0.15 & 0.45 & -4.4 & n.d. & -9.4 \\
\hline $\begin{array}{l}\text { Stoechiometry } \\
\text { [ligand/DNA] }\end{array}$ & $11-14$ & $11-14$ & 0.5 & $0.5-1$ & 4 \\
\hline
\end{tabular}

Docking simulations: Interactions with G4 (human telomeric sequence Tel22). Docking studies were performed to decipher the binding modes of TPE-Gir with Tel22 (in $\mathrm{Na}^{+}$conditions, PDB ID: 143D), taking into account indirectly the flexibility of $G 4$ through calculations on several conformations available from NMR coordinates, see methodology in the Supplementary Information). The most stable docking solution depicts a TPE-Gir binding mode in a wide groove of Tel22 (see Figure 7). Given the branched and propeller-like conformation of TPE-Gir, numerous close contacts, were observed with several residues along the G4 target (i.e. 86 contacts at a distance $<3.5 \AA$ ) , in particular $\pi$-type interactions between TPE-Gir aromatic core and four guanine residues (G2/G10 from the first tetrad and G3/G9 from second tetrad, see Figure 7A), some in a perpendicular (T-shape) interaction mode. In addition, a series of $\mathrm{H}$-bonds and electrostatic interactions between the quaternary ammoniums at the TPE-Gir extremities with Tel22 were observed, (see details in Figure 7 B-D). Regarding the TPE-Gir 'wings' labelled \#1, \#2 and \#3 in Figure 7A, five $\mathrm{H}$-bonds involving TPE-Gir amide fragments 
were found. Moreover, two cationic quaternary ammoniums of TPE-Gir (wings \#2 and \#3) are close to phosphate groups of Tel22 (5.8 and $6.3 \AA$ for N-P distances, see Figure 7C-D), a distance that can likely evolve regarding the flexibility of terminal groups in the four wings of TPE-Gir. Only one branch of TPE-Gir (wing \#4) points outside the core of the target, without any particular close contact. Globally, the binding mode of TPE-Gir ligand within a G4 groove therefore involves a series of electrostatic interactions, $\mathrm{H}$-bonds and $\pi$-type interactions, distributed differently among the four wings of TPE-Gir.
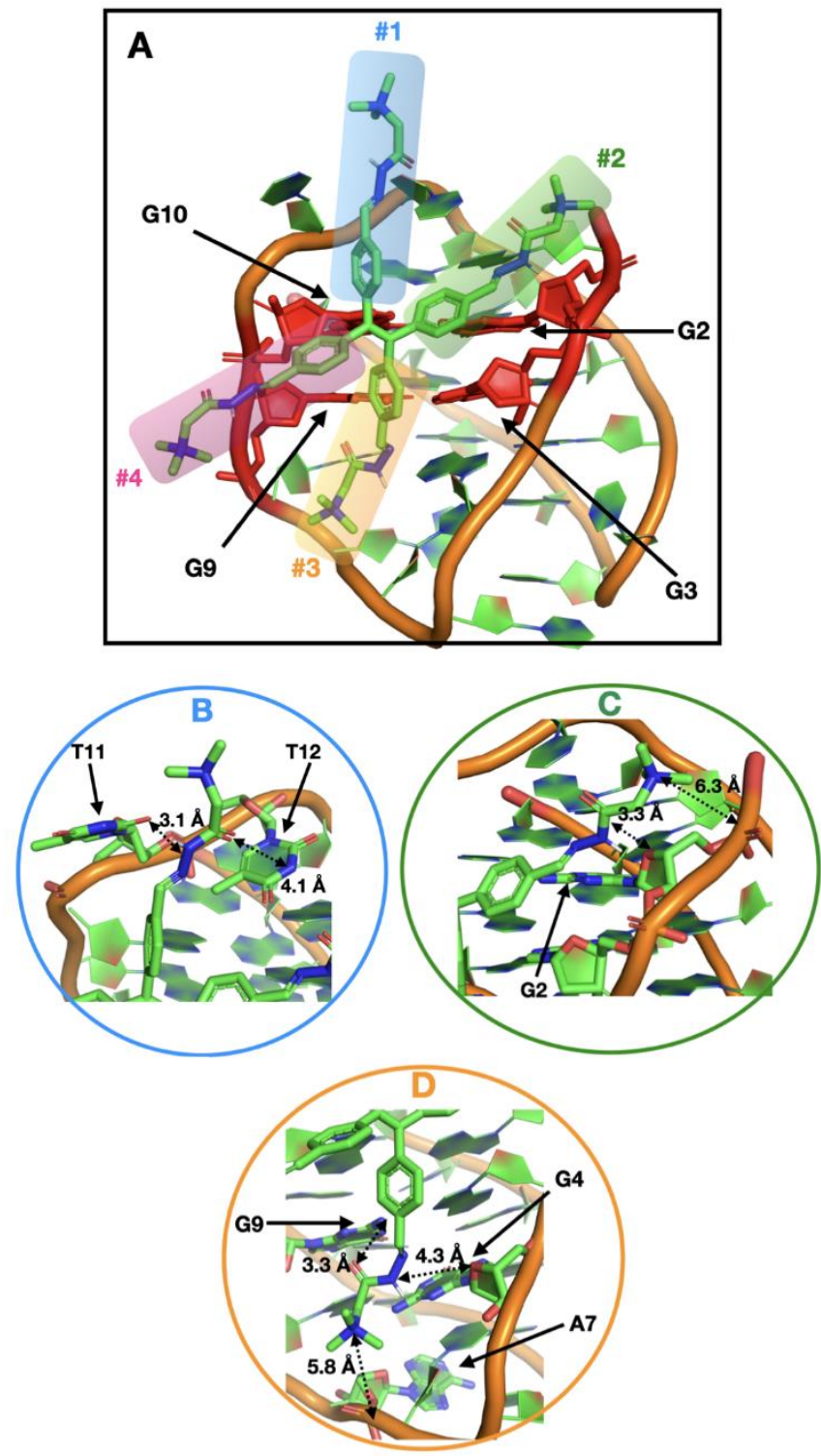

Figure 7. A. Most stable docking solution of TPE-Gir (stick representation, green) in the groove of Tel22 (cartoon representation, conformation \#1 from PDB ID: 143d). The four wings of TPE-Gir are labelled from \#1 to \#4. The four guanine residues that are involved in stacking interactions with TPE-Gir, i.e., G2/G10 ( $1^{\text {st }}$ tetrad) and G3/G9 ( $2^{\text {nd }}$ tetrad), are represented in sticks (color red); B-D. Zooms on the interactions between TPE-Gir wing and Tel 22 (see colour code for the wing number in A).: $\mathrm{H}$-bonds and electrostatic interactions are highlighted with black arrows.

Docking simulations: Interactions with DNA. For docking calculations with a dsDNA, a double helix of 43 base pairs was considered. Our docking protocol was repeated with different docking parameters to increase the probability of finding the minimum binding energy of the TPE-Gir/dsDNA complex (see computational details, Figures S8-S9). The most stable binding mode shows a binding of TPE-Gir in a DNA minor groove (Figure 8). Two wings of the ligand (\#2 and \#3, see Figure 8), are deeply docked in the minor groove whereas the two other wings point in opposite directions. The two deeply docked aromatic moieties are not involved in $\pi$-type interactions (as was observed for TPEGir/G4 complex) but rather in van der Waals interactions with dsDNA backbone. The four quaternary ammonium groups of TPE-Gir are all involved in electrostatic interactions with DNA phosphate groups (Figure 8B-D), in contrast to what was observed for TPE-Gir/Tel22 complex, in which only 2 wings over 4 were involved in electrostatic interactions. In comparison with TPE-Gir/Tel22 complex, the affinity of the TPE-Gir ligand to dsDNA is thus coming from numerous and stronger electrostatic interactions (but no $\pi$-type interactions). Although the propeller conformation of TPE core is unlikely to enter in between dsDNA base pairs, it is worth mentioning that our docking simulations in a rigid target approach limits the possibilities to find intercalation modes. Therefore, intercalation in between base pairs, although unlikely from our experience, cannot be totally excluded. The minor groove binding could be a first step with a subsequent intercalation process, facilitated by the electrostatic anchoring of the four TPE-Gir wings along dsDNA. 

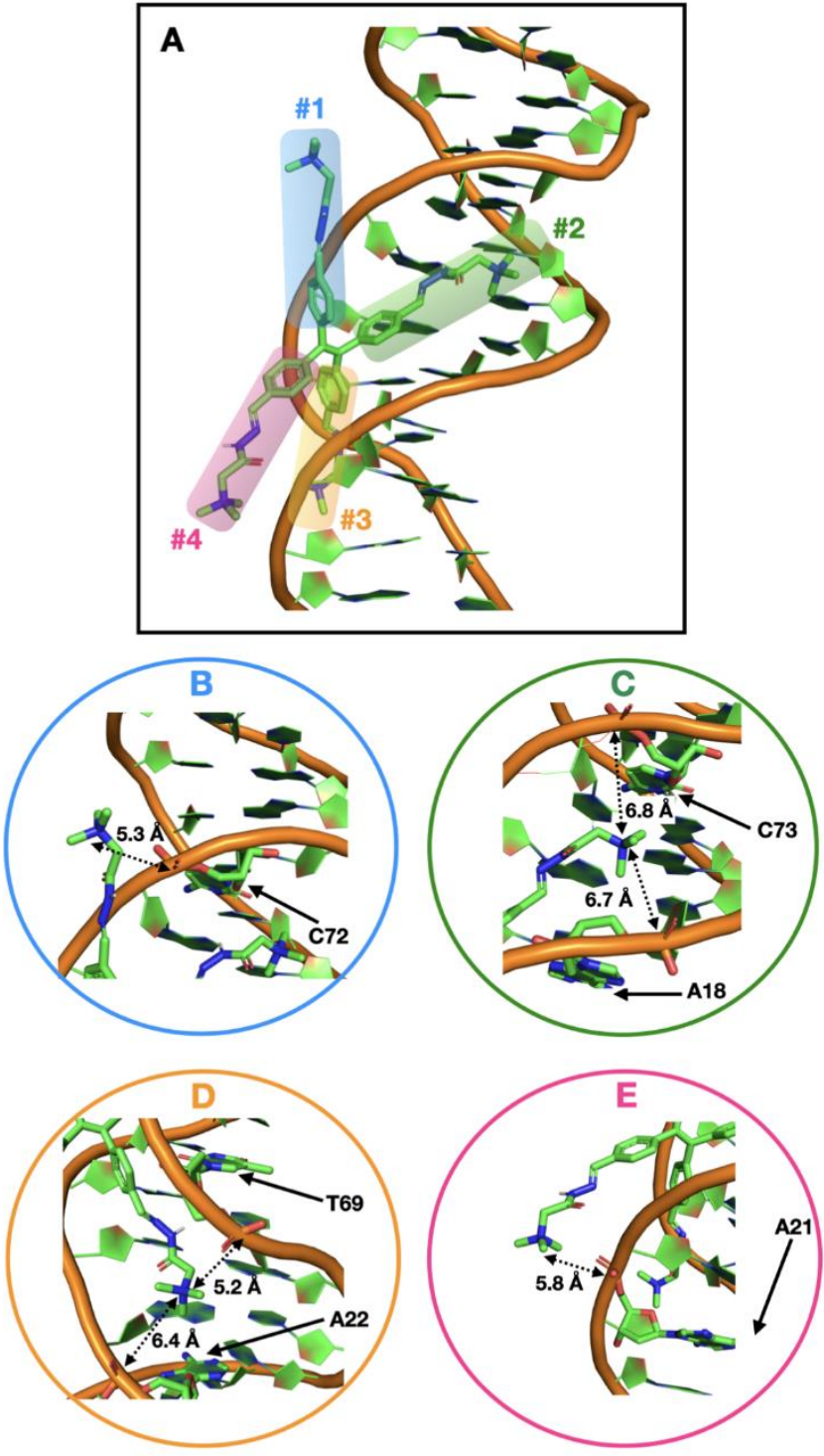

Figure 8. A. Zoom on the most stable docking solution of TPE-Gir (stick representation, green) in the minor groove of a model DNA (cartoon representation). The four wings of TPE-Gir are labelled from \#1 to \#4; B-D. Zooms on the electrostatic interaction between TPE-Gir wings and dsDNA (see colour code for the wing number in $\mathrm{A}$ ). Distances were measured between $\mathrm{N}$ and $\mathrm{P}$ atoms.

\section{Conclusion}

We reported herein the design, synthesis, self-assembly and nucleic acid recognition of a novel ligand featuring a tetraphenylethene aromatic core tethered to four quaternary ammonium groups through acylhydrazone spacers. We found that this compound leads to the formation, in water/THF mixtures, of fluorescent nanoparticles having diameters around 100-120 nm Detailed spectroscopic studies using single- and double-stranded DNA as templates reveal the strong propensity to intercalate into single-stranded DNA, the ability to bind into the minor groove of double-stranded DNA, and the selective binding to G-quadruplex. Finally, a selective binding of DNA G-quadruplex was evidenced. Those recognition events are quantified by isothermal titration calorimetry and the proposed binding models are supported by docking simulations. Given the versatility of the acylhydrazone ligation technique ${ }^{[28 a]}$ as well as the ability of this group to undergo photo-switching, ${ }^{[52]}$ there is plenty of room to expand the approach described here and tether different end-groups for fine-tuning selfassembly properties and modulate nucleic acids recognition.

\section{Experimental Section}

General procedures and materials. All solvents and reagents were purchased from commercial suppliers and used without further purifications. Oligonucleotides were purchased from Eurogentec as RP. Cartridge purification ( $\mathrm{dT}_{40}$ ) or RP-HPLC purification for FAM-dT40, TAMRA-dT 40 , and dT 40 -TAMRA (Ultrapure Gold, >95\% purity) in dried format or from Sigma Aldrich for CT-ssDNA and CT-DNA. TPE-Ald was synthesized according to reported literature procedure. ${ }^{[27]}$

NMR. ${ }^{1} \mathrm{H}$ Nuclear Magnetic Resonance (NMR) spectra were recorded at $400 \mathrm{MHz}$ (Bruker Avance 400) using deuterated water. Chemical shifts are reported in ppm relative to the residual solvent peak. Data are reported as follows: Chemical shifts ( $\delta)$, multiplicity (s for singlet, $d$ for doublet, and $m$ for multiplet), integration and coupling constant ( ${ }^{n} J$ in Hertz).

Mass spectrometry. Mass spectrometry analyses (positive mode) were carried out in the Laboratoire de Mesures Physiques, Université de Montpellier using a Micromass Q-Tof instrument.

HPLC. HPLC analyses were performed on a Waters HPLC 2695 (EC Nucleosil 300-5 $\mathrm{C}_{18}, 125 \times 3 \mathrm{~mm}$ ) column, Macherey - Nagel) equipped with a Waters 996 DAD detector. The following linear gradients of solvent B $(90 \%$ acetonitrile, $9.9 \%$ water, and $0.1 \%$ TFA) into solvent A $(99.9 \%$ water and $0.1 \%$ TFA) were used: 0 to $95 \%$ of solvent B in 5 min; flow 1 $\mathrm{ml} / \mathrm{min}$. Retention time $\left(\mathrm{t}_{\mathrm{R}}\right)$ are given in minutes. Semi-preparative RPHPLC were performed on a Waters 515 HPLC (VP Nucleodur 250-21 C18, HTec $7 \mu \mathrm{m}$ column, Macherey-Nagel) equipped with a Waters 2487 detector.

UV-Vis absorption and CD spectroscopy. UV-Vis absorption spectra were recorded at $20{ }^{\circ} \mathrm{C}$ on a UV-31 OOPC UVisco spectrophotometer in $10 \mathrm{~mm}$ quartz cells (Hellma). The spectra were recorded at $20{ }^{\circ} \mathrm{C}$ between 200 and $650 \mathrm{~nm}$, with a bandwidth of $1 \mathrm{~nm}$, time per point $1 \mathrm{~s}$. For studies with ssDNA and dsDNA, CD spectra were recorded at $20 \circ \mathrm{C}$ using $10 \mathrm{~mm}$ and $2 \mathrm{~mm}$ quartz cells (Hellma) at the Laboratoire de Mesures Physiques, IBMM - Université de Montpellier. For studies with G-quadruplexes, UVVis absorption measurements were recorded using a ChirascanTM Plus CD Spectrometer (Applied Photophysics) at the University of Mons. The measurements were carried out using $2 \mathrm{~mm}$ suprasil quartz cells from Hellma Analytics. The spectra were recorded at $20^{\circ} \mathrm{C}$ between $225 \mathrm{~nm}$ and $600 \mathrm{~nm}$, with a bandwidth of $1 \mathrm{~nm}$, time per point $1 \mathrm{~s}$. The buffer water solvent was Tris-EDTA (TE) prepared from $1 \mathrm{M}$ Tris-Cl and $0.5 \mathrm{M}$ EDTA to achieve a $10 \mathrm{mM}$ Tris-Cl and $1 \mathrm{mM}$ EDTA final buffer at $\mathrm{pH} 7.5$. The buffered water solvent reference spectra were used as baselines and were automatically subtracted from the CD and UV-vis spectra of the samples. All the spectra were plotted by using OriginPro 2018 software.

Fluorescence spectroscopy. Fluorescence analyses were carried out on a HITACHI fluorescence spectrophotometer F-2500. For studies with G-quadruplexes, emission spectra of TPEGir/oligonucleotides mixtures were recorded at the University of Mons using a ChirascanTM Plus CD spectrophotometer (Applied Photophysics) equipped for fluorescence measurements. The measurements were carried out using $4 \mathrm{~mm}$ by $10 \mathrm{~mm}$ suprasil quartz cells from Hellma Analytics. The spectra were recorded at $20{ }^{\circ} \mathrm{C}$ between 350 and $650 \mathrm{~nm}$ with an excitation wavelength at $269 \mathrm{~nm}$ and a bandwidth of $1 \mathrm{~nm}$. 
Dynamic Light Scattering. Particle size measurements were carried out at $25^{\circ} \mathrm{C}$ from a $0.025 \mathrm{mM}$ solution of TPE-Gir in $3 \mathrm{~mL} \mathrm{THF} / \mathrm{H}_{2} \mathrm{O} 99 / 1$ (v/v) on a Zetasizer Nano ZS (Malvern, United Kingdom) using 10 mm quartz cells (Hellma).

Fluorescence Resonance Energy Transfer (FRET) Assays. FRET assays were performed using FAM-dT 40 , TAMRA-dT 40 and $\mathrm{dT}_{40}-\mathrm{TAMRA}$. The fluorescence emission spectra were recorded at $20^{\circ} \mathrm{C}$ on a fluorescence spectrophotometer FLX-Xenius XMF using $\lambda_{\mathrm{ex}}=495 \mathrm{~nm}$ and $\lambda_{\mathrm{em}}=500-650 \mathrm{~nm}$

Isothermal Titration Calorimetry. The thermodynamic binding parameters were recorded at $20^{\circ} \mathrm{C}$ on a MicroCal/Malvern PEAK-ITC (Malvern Panalytics) instrument. The titration cell was filled with a solution of $25 \mu \mathrm{M}$ single-stranded $\mathrm{dT}_{40}$ DNA or Tel22, and the syringe was loaded with a 0.3-3 mM solution of TPE-Gir. For each experiment, a series of injections of ligand from a rotating syringe (speed $750 \mathrm{rpm}$ ) were made into the thermostatic cell (initial delay of $60 \mathrm{~s}$, duration of $2 \mathrm{~s}$ and spacing of $120 \mathrm{~s}$ ). Control experiments were performed by adding the ligand solution to the cell containing the buffer. The corrected ITC titrations were processed using the MicroCal Origin software.

Transmission Electronic Microscopy. Transmission Electron Microscopy (TEM) was carried out at the plateforme de Microscopie Électronique et Analytique, Université de Montpellier using a JEOL 1200 EXII $120 \mathrm{kV}$ instrument.

Molecular Docking. TPE-Gir was built within the Avogadro molecular editor.[53] Molecular mechanics calculations were then performed to optimize the geometry of the TPE-Gir molecule. For this, a two-step minimization procedure, i.e., a steepest descent optimization followed by a conjugate gradient optimization (10,000 steps), was performed with the General Amber Force Field (GAFF). ${ }^{[54]}$ The energy convergence criterion was set at $10^{-7} \mathrm{~kJ}_{\mathrm{mol}}^{-1}$ for the energy minimization. The coordinates of the G-quadruplex (G4) were obtained from the Protein Data Bank (PDB ID: 143D). The NMR conformations of the G4 were extracted to perform ensemble docking calculations, i.e., six conformations for the 143D target. Docking calculations were performed with the QuickVina-W package, ${ }^{[55]}$ a fork of AutoDock Vina package, optimized for wide search space and blind docking. ${ }^{[56]}$ As we have no a priori knowledge of the TPE-Gir binding mode along the G4 structure, a sufficiently large grid was built around each G4 conformation to allow the exploration of the entire G4 surface during the docking calculations. A large grid size of $40 \times 40 \times 40 \AA^{3}$ with a spacing of $1.0 \AA$ was thus considered. The center of the grid box was located on the centre-of-mass of the G4 targets. Our docking protocol was repeated with several docking algorithm parameters to increase the probability of finding the minimum binding energy of the complex. As the grid presents an important size, a starting exhaustiveness value of 64 was chosen, a larger one than the default value, i.e., eight. ${ }^{[57]}$ The docking simulations were then replicated with larger exhaustiveness values, i.e., 128, 256, 512 and 1024, to ensure the convergence of the optimum docking solution. TPE-Gir was set as a flexible entity with flexibility on torsions of the terminal groups of the four TPE-Gir wings. The 10 most energetically favourable complexes were retained for each docking calculation. The PyMOL molecular visualization system was used to depict the results docking calculations. ${ }^{[58]}$ For the calculations on TPE-Gir/Tel complex, for each replica of our docking protocol, the best docking solution was always obtained with the conformation \#1 of Tel22 (see docking scores in Figure S6). Moreover, a very similar TPE-Gir binding mode is observed from the superimposition of the best docking solutions issued from each docking replica, which indicates a reliable convergence of the docking search algorithm (Figure S7). For the TPE-Gir/dsDNA complex, the replica converge to a very similar docking solution regarding both the binding energy scores (Figure S8) as well as on the geometries, see the superimposition of the best docking poses for each replica in Figure S9.

Synthesis and characterization of TPE-Gir. TPE-Ald $(11.3 \mathrm{mg}, 25.4$ $\mu$ moles) and Girard's reagent T (38.2 mg, 226.5 umoles, 8 eq.) were mixed in ethanol $(2 \mathrm{~mL})$ and the reaction mixture was stirred at reflux overnight. The desired product was isolated in $71 \%$ yield by semi-preparative reverse-phase HPLC (linear gradient $\mathrm{H}_{2} \mathrm{O} \rightarrow \mathrm{H}_{2} \mathrm{O}$ /acetonitrile 80/20 in 20 mins). ${ }^{1} \mathrm{H} \mathrm{NMR}^{[59]}\left(\mathrm{D}_{2} \mathrm{O}\right)$ shows a $7 / 3$ mixture of 2 isomers, most probably $\mathrm{E} / \mathrm{Z}$ acylhydrazone isomers: $8.16\left(\mathrm{~s}, 0.7 \mathrm{H}, \mathrm{H}_{\mathrm{c}}\right), 7.94\left(\mathrm{~s}, 0.3 \mathrm{H}, \mathrm{H}_{\mathrm{c}^{\prime}}\right), 7.56$

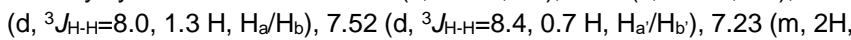
$\left.\mathrm{H}_{\mathrm{a}} / \mathrm{H}_{\mathrm{b}}+\mathrm{H}_{\mathrm{a}^{\prime}} / \mathrm{H}_{\mathrm{b}^{\prime}}\right), 4.68$ (s, $0.6 \mathrm{H}, \mathrm{H}_{\mathrm{d}^{\prime}}$ ), 4.20 (s, $\left.1.3 \mathrm{H}, \mathrm{H}_{\mathrm{d}}\right), 3.34\left(\mathrm{~s}, 9 \mathrm{H}, \mathrm{H}_{\mathrm{e}}\right.$ ); ESI-MS: calcd for $\left[\mathrm{C}_{50} \mathrm{H}_{68} \mathrm{~N}_{12} \mathrm{O}_{4}\right]^{4+}$ 225.1366, found 225.1379; $\left[\mathrm{C}_{50} \mathrm{H}_{68} \mathrm{~N}_{12} \mathrm{O}_{4}-\mathrm{H}\right]^{3+}$ 299.8464, found 300.18; [ $\left.\mathrm{C}_{50} \mathrm{H}_{68} \mathrm{~N}_{12} \mathrm{O}_{4}-2 \mathrm{H}\right]^{2+} 449.2660$, found 449.27

Preparation of ligand in water/THF mixtures for AIE studies. The Aggregation-Induced Emission (AIE) effect was determined by preparing solution of $6 \mu \mathrm{L}$ TPE-Gir (10 mM in water) in $3 \mathrm{~mL}$ (final concentration 0.02 $\mathrm{mM})$ in different solvent ratio of THF in $\mathrm{H}_{2} \mathrm{O}(0 \%, 20 \%, 50 \%, 70 \%, 90 \%$, 95\%, 96\%, 97\%, 98\%, 99\%).

Preparation of ligand:oligonucleotide complexes. UV-Vis and fluorescence titration experiments using ssCT-DNA, dT40, CT-DNA (stock solutions in water, $0.16 \mu \mathrm{M}$ for SsCT-DNA and CT-DNA and $133 \mu \mathrm{M}$ for $\mathrm{dT}_{40}$ ), were carried out in $10 \mathrm{~mm}$ quartz cells by mixing $6 \mu \mathrm{L}$ of a $10 \mathrm{mM}$ solution of TPE-Gir (final concentration of TPE-Gir $0.02 \mathrm{mM}$ ) and oligonucleotides (final concentrations of $0.2 \mathrm{nM}$ to $8 \mathrm{nM}$ for SSCT-DNA and $0.1 \mathrm{nM}$ to $4 \mathrm{nM}$ for CT-DNA) in HEPES. Similarly, CD spectroscopy analyses were carried out by mixing $19.6 \mu \mathrm{L}$ of a solution of $\mathrm{dT}_{40}$ (final volume of $200 \mu \mathrm{L}$ ) and TPE-Gir (final concentrations of $0.012 \mathrm{mM}$ to 0.6 $\mathrm{mM}$ ) in $2 \mathrm{~mm}$ quartz cells, or $39.6 \mu \mathrm{L}$ of a solution of CT-DNA (final volume of $3 \mathrm{~mL}$ ) and TPE-Gir (final concentrations of $2 \mu \mathrm{M}$ to $60 \mu \mathrm{M}$ ) in $10 \mathrm{~mm}$ quartz cells. Molar ratios vary between 0.5 and 10 and are expressed in ligand per nucleobase for ssDNA/dT 40 , and ligand per base pair for dsDNA

\section{Acknowledgements}

We thank the ANR (ANR-17-CE07-0042-01) for funding. Research in Mons was supported by the University of Mons, the Wallonia Region, and the Fund for Scientific Research (F.R.S.FNRS) under the grant EOS No. 30650939 (PRECISION). SR and CK acknowledge the Région Languedoc-Roussillon (Research Grant “Chercheur(se)s d'Avenir -2015-005984) and the FEDER program (Fonds Européen de Développement Régional) for funding. CK also thanks UMONS for a Ph.D. grant. We thank Dr. Prisca Boisguerin and Dr. Sébastien Deshayes for access to the DLS instrument, Emeric Audfray for assistance with the MicroCal PEAK-ITC equipment (Malvern Panalytical), Dr. Erwan Oliviero for assistance with the TEM analyses, and Dr. Baptiste Legrand for assistance with CD. Computational resources have been provided by the Consortium des Équipements de Calcul Intensif (CÉCI), funded by the F.R.S.FNRS under Grant No. 2.5020.11 and by the Wallonia Region.

Keywords: Self-assembly • Molecular recognition • Nucleic acids $•$ G-quadruplex $•$ Aggregation induced emission

[1] S. Cantekin, T. F. A. de Greef, A. R. A. Palmans, Chem. Soc. Rev. 2012, 41, 6125-6137.

[2] a) M. F. J. Mabesoone, S. Kardas, H. Soria-Carrera, J. Barberá, J. M de la Fuente, A. R. A. Palmans, M. Fossépré, M. Surin, R. Martin Rapún, Mol Syst Des Eng 2020, 5, 820-828; b) C. Kulkarni, E. W. Meijer, A. R. A. Palmans, Acc. Chem. Res. 2017, 50, 1928-1936.

[3] Y. Yang, M. W. Urban, Chem. Soc. Rev. 2013, 42, 7446-7467.

[4] a) S. van Dun, J. Schill, L. G. Milroy, L. Brunsveld, Chem. Eur. J. 2018, 24, 16445-16451; b) M. H. Bakker, C. C. Lee, E. W. Meijer, P. Y. W Dankers, L. Albertazzi, Acs Nano 2016, 10, 1845-1852; c) K. PetkauMilroy, L. Brunsveld, Org. Biomol. Chem. 2013, 11, 219-232; d) K. Petkau-Milroy, M. H. Sonntag, L. Brunsveld, Chem. Eur. J. 2013, 19 , 
10786-10793; e) D. A. Uhlenheuer, K. Petkau, L. Brunsveld, Chem. Soc. Rev. 2010, 39, 2817-2826.

[5] M. Surin, S. Ulrich, Chemistryopen 2020, 9, 480-498

[6] a) J. Rubio-Magnieto, T. A. Phan, M. Fossépré, V. Matot, J. Knoops, T. Jarrosson, P. Dumy, F. Serein-Spirau, C. Niebel, S. Ulrich, M. Surin, Chem. Eur. J. 2018, 24, 706-714; b) S. M. Hafshejani, S. M. D. Watson, E. M. Tuite, A. R. Pike, Chem. Eur. J. 2015, 21, 12611-12615; c) S. MoradpourHafshejani, J. H. Hedley, A. O. Haigh, A. R. Pike, E. M. Tuite, RSC Adv. 2013, 3, 18164-18172; d) K. C. Hannah, B. A. Armitage, Acc. Chem. Res. 2004, 37, 845-853; e) M. M. Wang, G. L. Silva, B. A. Armitage, J. Am. Chem. Soc. 2000, 122, 9977-9986.

[7] L. Albertazzi, F. J. Martinez-Veracoechea, C. M. A. Leenders, I. K. Voets, D. Frenkel, E. W. Meijer, Proc. Natl. Acad. Sci. USA 2013, 110 12203-12208.

[8] P. Evenou, J. Rossignol, G. Pembouong, A Gothland, D. Colesnic, R. Barbeyron, S. Rudiuk, A. G. Marcelin, M. Menand, D. Baigl, V. Calvez, L. Bouteiller, M. Sollogoub, Angew. Chem. Int. Ed. 2018, 57, 77537758

[9] Y. Zhang, E. Petit, M. Barboiu, Chempluschem 2018, 83, 354-360.

[10] P. G. A Janssen, S. Jabbari-Farouji, M. Surin, X. Vila, J. C. Gielen, T. F. de Greef, M. R. Vos, P. H. Bomans, N. A. Sommerdijk, P. C. Christianen, P. Leclère, R. Lazzaroni, P. van der Schoot, E. W. Meijer, A. P. H. J. Schenning, J. Am. Chem. Soc. 2009, 131, 1222-1231.

[11] a) D. Paolantoni, S. Cantel, P. Dumy, S. Ulrich, Int J Mol Sci 2015, 16 3609-3625; b) D. Paolantoni, J. Rubio-Magnieto, S. Cantel, J. Martinez, P. Dumy, M. Surin, S. Ulrich, Chem. Commun. 2014, 50, 14257-14260.

[12] a) N. Laroui, M. Coste, L. Lichon, Y. Bessin, M. Gary-Bobo, G. Pratviel, C. Bonduelle, N. Bettache, S. Ulrich, Int J. Pharm. 2019, 569; b) M. V. Ishutkina, A. R. Berry, R. Hussain, O. G. Khelevina, G. Siligardi, E. Stulz, Eur. J. Org. Chem. 2018, 2018, 5054-5059; c) G. Sargsyan, A. A Schatz, J. Kubelka, M. Balaz, Chem. Commun. 2013, 49, 1020-1022; d L. A. Fendt, I. Bouamaied, S. Thöni, N. Amiot, E. Stulz, J. Am. Chem. Soc. 2007, 129, 15319-15329.

[13] A. D'Urso, S. Nardis, G. Pomarico, M. E. Fragala, R. Paolesse, R. Purrello, J. Am. Chem. Soc. 2013, 135, 8632-8638.

[14] J. Rubio-Magnieto, M. Kumar, P. Brocorens, J. Idé, S. J. George, R Lazzaroni, M. Surin, Chem. Commun. 2016, 52, 13873-13876.

[15] I. Kocsis, A. Rotaru, Y. M. Legrand, I. Grosu, M. Barboiu, Chem. Commun. 2016, 52, 386-389.

[16] M. Surin, P. G. A. Janssen, R. Lazzaroni, P. Leclère, E. W. Meijer, A. P. H. J. Schenning, Adv. Mater. 2009, 21, 1126-1130.

[17] a) P. G. A. Janssen, N. J. M. Brankaert, X. Vila, A. P. H. J. Schenning Soft Matter 2010, 6, 1494-1502; b) P. G. A. Janssen, S. Jabbari-Farouji, M. Surin, X. Vila, J. C. Gielen, T. F. A. de Greef, M. R. J. Vos, P. H. H. Bomans, N. A. J. M. Sommerdijk, P. C. M. Christianen, P. Leclere, R. Lazzaroni, P. van der Schoot, E. W. Meijer, A. P. H. J. Schenning, J. Am. Chem. Soc. 2009, 131, 1222-1231.

[18] E. Bartolami, Y. Bessin, N. Bettache, M. Gary-Bobo, M. Garcia, P. Dumy, S. Ulrich, Org. Biomol. Chem. 2015, 13, 9427-9438.

[19] G. M. ter Huurne, P. Chidchob, A. G. Long, A. Martinez, A. R. A. Palmans, G. Vantomme, Chem. Eur. J. 2020.

[20] C. Bouillon, Y. Bessin, S. Ulrich, unpublished results.

[21] a) B. Jiang, C. W. Zhang, X. L. Shi, H. B. Yang, Chinese J Polym Sci 2019, 37, 372-382; b) D. D. La, S. V. Bhosale, L. A. Jones, S. V. Bhosale, Acs Appl Mater Inter 2018, 10, 12189-12216; c) Z. J. Zhao, J. W. Y. Lam, B. Z. Tang, J. Mat. Chem. 2012, 22, 23726-23740.

[22] a) J. Mei, N. L. C. Leung, R. T. K. Kwok, J. W. Y. Lam, B. Z. Tang Chem. Rev. 2015, 115, 11718-11940; b) R. T. K. Kwok, C. W. T. Leung, J. W. Y. Lam, B. Z. Tang, Chem. Soc. Rev. 2015, 44, 42284238; c) J. Mei, Y. N. Hong, J. W. Y. Lam, A. J. Qin, Y. H. Tang, B. Z. Tang, Adv. Mater. 2014, 26, 5429-5479; d) Y. N. Hong, J. W. Y. Lam, B. Z. Tang, Chem. Soc. Rev. 2011, 40, 5361-5388.

[23] B. Li, T. He, X. Shen, D. T. Tang, S. C. Yin, Polym Chem-Uk 2019, 10 796-818.

[24] L. Xu, Z. C. Zhu, X. Zhou, J. G. Qin, C. L. Yang, Chem. Commun. 2014 $50,6494-6497$

[25] a) L. Xu, Z. C. Zhu, D. Q. Wei, X. Zhou, J. G. Qin, C. L. Yang, Acs App/ Mater Inter 2014, 6, 18344-18351; b) Y. N. Hong, S. J. Chen, C. W. T. Leung, J. W. Y. Lam, B. Z. Tang, Chem. Asian J. 2013, 8, 1806-1812.

[26] a) C. Kotras, M. Fossépré, M. Roger, V. Gervais, S. Richeter, P. Gerbier, S. Ulrich, M. Surin, S. Clément, Front. Chem. 2019, 7, Article 493; b) Q. Zhang, Y. C. Liu, D. M. Kong, D. S. Guo, Chem. Eur. J. 2015, 21, 13253-13260; c) Y. N. Hong, H. Xiong, J. W. Y. Lam, M. Haussler, J. Z. Liu, Y. Yu, Y. C. Zhong, H. H. Y. Sung, I. D. Williams, K S. Wong, B. Z. Tang, Chem. Eur. J. 2010, 16, 1232-1245; d) Y. N. Hong, M. Haussler, J. W. Y. Lam, Z. Li, K. K. Sin, Y. Q. Dong, H. Tong, J. Z. Liu, A. J. Qin, R. Renneberg, B. Z. Tang, Chem. Eur. J. 2008, 14, 6428-6437.

[27] W. Drozdz, C. Bouillon, C. Kotras, S. Richeter, M. Barboiu, S. Clement A. R. Stefankiewicz, S. Ulrich, Chem. Eur. J. 2017, 23, 18010-18018.

[28] a) D. K. Kölmel, E. T. Kool, Chem. Rev. 2017, 117, 10358-10376; b) W. G. Skene, J.-M. P. Lehn, Proc. Natl. Acad. Sci. USA 2004, 101, 8270 8275

[29] a) N. Zhao, M. Li, Y. L. Yan, J. W. Y. Lam, Y. L. Zhang, Y. S. Zhao, K. S. Wong, B. Z. Tang, J. Mater. Chem. C 2013, 1, 4640-4646; b) X. L.
Yang, N. X. Wang, L. M. Zhang, L. R. Dai, H. W. Shao, X. Y. Jiang, Nanoscale 2017, 9, 4770-4776.

[30] a) Q. Wang, Q. Zhang, Q. W. Zhang, X. Li, C. X. Zhao, T. Y. Xu, D. H. Qu, H. Tian, Nat. Commun. 2020, 11; b) A. R. Sapala, S. Dhawan, V. Haridas, RSC Adv. 2017, 7, 26608-26624.

[31] P. Besenius, G. Portale, P. H. H. Bomans, H. M. Janssen, A. R. A Palmans, E. W. Meijer, Proc. Natl. Acad. Sci. USA 2010, 107, 1788817893.

[32] a) M. Balaz, S. Tannir, K. Varga, Coord. Chem. Rev. 2017, 349, 66-83 b) M. Surin, Polym Chem-Uk 2016, 7, 4137-4150; c) A. Ruiz-Carretero, P. G. A. Janssen, A. Kaeser, A. P. H. J. Schenning, Chem. Commun. 2011, 47, 4340-4347.

[33] a) H. Chen, S. P. Meisburger, S. A. Pabit, J. L. Sutton, W. W. Webb, L. Pollack, Proc. Natl. Acad. Sci. USA 2012, 109, 799-804; b) M. C. Murphy, I. Rasnik, W. Cheng, T. M. Lohman, T. J. Ha, Biophys J 2004 86, 2530-2537; c) B. Tinland, A. Pluen, J. Sturm, G. Weill, Macromolecules 1997, 30, 5763-5765.

[34] S. Ulrich, P. Dumy, Chem. Commun. 2014, 50, 5810-5825.

[35] In the present case, the shift to longer wavelength in the absorption spectra is indicative of a better conjugation in the ligand, which is probably due to a better planarization enforced by its stacking with nucleobases.

[36] a) N. C. Garbett, P. A. Ragazzon, J. B. Chaires, Nat Protoc 2007, 2, 3166-3172; b) M. Eriksson, B. Norden, Method Enzymol 2001, 340, 68 98; c) M. Monnot, O. Mauffret, E. Lescot, S. Fermandjian, Eur J Biochem 1992, 204, 1035-1039; d) H. Porumb, Prog Biophys Mol Bio 1978, 34, 175-195

[37] N. J. Pritchar, A. Blake, A. R. Peacocke, Nature 1966, 212, 1360-1361.

[38] H. S. Rye, A. N. Glazer, Nucleic Acids Res. 1995, 23, 1215-1222.

[39] N. Sinha, L. Stegemann, T. T. Y. Tan, N. L. Doltsinis, C. A. Strassert, F. E. Hahn, Angew. Chem. Int. Ed. 2017, 56, 2785-2789.

[40] a) H. M. Berman, P. R. Young, Annu Rev Biophys Bio 1981, 10, 87 114 ; b) R. W. Armstrong, U. P. Strauss, T. Kurucsev, J. Am. Chem. Soc. 1970, 92, 3174-3181.

[41] N. H. List, J. Knoops, J. Rubio-Magnieto, J. Idé, D. Beljonne, P. Norman, M. Surin, M. Linares, J. Am. Chem. Soc. 2017, 139, 1494714953.

[42] J. Kypr, I. Kejnovska, K. Bednarova, M. Vorlıckova, in Applications in Stereochemical Analysis of Synthetic Compounds, Natural Products, and Biomolecules, Vol. 2 (Eds.: N. Berova, P. L. Polavarapu, K. Nakanishi, R. W. Woody), Wiley, 2012.

[43] a) S. Neidle, Nat. Rev. Chem. 2017, 1; b) B. Maji, S. Bhattacharya, Chem. Commun. 2014, 50, 6422-6438; c) G. W. Collie, G. N Parkinson, Chem. Soc. Rev. 2011, 40, 5867-5892; d) S. Balasubramanian, S. Neidle, Curr Opin Chem Biol 2009, 13, 345-353.

[44] a) S. Asamitsu, T. Bando, H. Sugiyama, Chem. Eur. J. 2019, 25, 417 430; b) D. Monchaud, M. P. Teulade-Fichou, Org. Biomol. Chem. 2008 6, 627-636.

[45] a) F. Caporaletti, J. Rubio-Magnieto, M. Lo, J. F. Longevial, C. Rose, S. Clément, A. van der Lee, M. Surin, S. Richeter, J Porphyr Phthalocya 2020, 24, 340-349; b) J. Rubio-Magnieto, S. Kajouj, F. Di Meo, M. Fossépré, P. Trouillas, P. Norman, M. Linares, C. Moucheron, M. Surin, Chem. Eur. J. 2018, 24, 15577-15588; c) J. Rubio-Magnieto, F. Di Meo, M. Lo, C. Delcourt, S. Clément, P. Norman, S. Richeter, M. Linares, M. Surin, Org. Biomol. Chem. 2015, 13, 2453-2463.

[46] a) J. X. Dai, M. Carver, D. Z. Yang, Biochimie 2008, 90, 1172-1183; b) J. X. Dai, C. Punchihewa, A. Ambrus, D. Chen, R. A. Jones, D. Z. Yang, Nucleic Acids Res. 2007, 35, 2440-2450; c) A. Ambrus, D. Chen J. X. Dai, T. Bialis, R. A. Jones, D. Z. Yang, Nucleic Acids Res. 2006, 34, 2723-2735.

[47] J. S. Hudson, L. Ding, V. Le, E. Lewis, D. Graves, Biochemistry 2014 53, 3347-3356.

[48] D. Renciuk, J. Zhou, L. Beaurepaire, A. Guedin, A. Bourdoncle, J. L. Mergny, Methods 2012, 57, 122-128.

[49] a) G. N. Parkinson, F. Cuenca, S. Neidle, J. Mol. Biol. 2008, 381, 1145 1156; b) G. N. Parkinson, R. Ghosh, S. Neidle, Biochemistry 2007, 46, 2390-2397.

[50] a) W. Drozdz, A. Walczak, Y. Bessin, V. Gervais, X. Y. Cao, J. M. Lehn, S. Ulrich, A. R. Stefankiewicz, Chem. Eur. J. 2018, 24, 10802-10811; b) W. Drożdż, Y. Bessin, V. Gervais, X.-Y. Cao, J.-M. Lehn, A. R Stefankiewicz, S. Ulrich, Chem. Eur. J. 2018, 24, 1518-1521.

[51] A. Wolfe, G. H. Shimer, T. Meehan, Biochemistry 1987, 26, 6392-6396.

[52] a) E. Weyandt, G. M. ter Huurne, G. Vantomme, A. J. Markvoort, A. R. A. Palmans, E. W. Meijer, J. Am. Chem. Soc. 2020, 142, 6295-6303; b) D. J. van Dijken, P. Kovaricek, S. P. Ihrig, S. Hecht, J. Am. Chem. Soc. 2015, 137, 14982-14991.

[53] M. D. Hanwell, D. E. Curtis, D. C. Lonie, T. Vandermeersch, E. Zurek G. R. Hutchison, J Cheminformatics 2012, 4.

[54] J. M. Wang, R. M. Wolf, J. W. Caldwell, P. A. Kollman, D. A. Case, J Comput Chem 2004, 25, 1157-1174.

[55] N. M. Hassan, A. A. Alhossary, Y. G. Mu, C. K. Kwoh, Sci Rep-Uk 2017, 7

[56] O. Trott, A. J. Olson, J Comput Chem 2010, 31, 455-461.

[57] M. M. Jaghoori, B. Bleijlevens, S. D. Olabarriaga, J Comput Aid Mol Des 2016, 30, 237-249. 
[58] Delano, W. L. (2002). The PyMOL Molecular Graphics System.

Available online at: https://ci.nii.ac.jp/naid/10020095229/en

[59] see Figure S2 for protons assignment. 


\section{Entry for the Table of Contents}

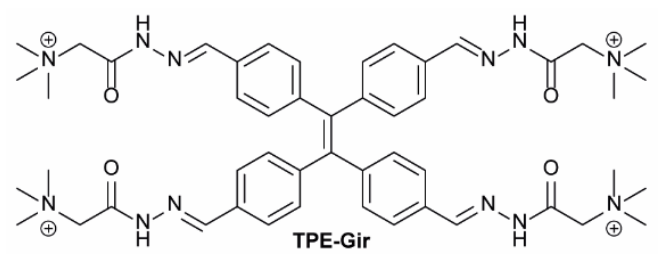

TPE-Gir self-assembles into fluorescent nanoparticles and interact with nucleic acids (single- and double-stranded DNA), with selective binding to G-quadruplexes. 